Assistance to refugees, returnees, displaced persons, and other vulnerable groups

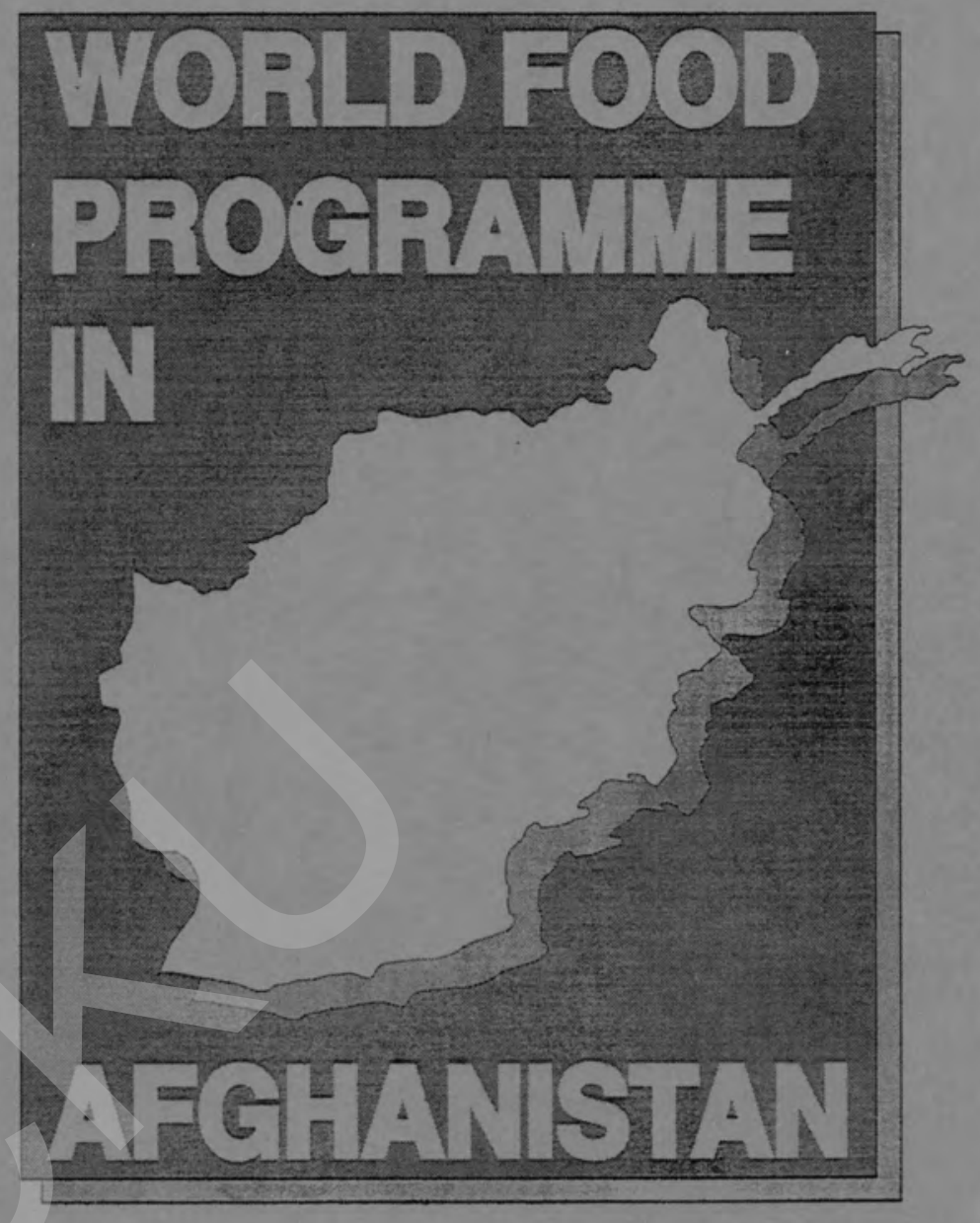

\title{
SITUATION REPORT NO. 3
}

\section{OCTOBER 1995}

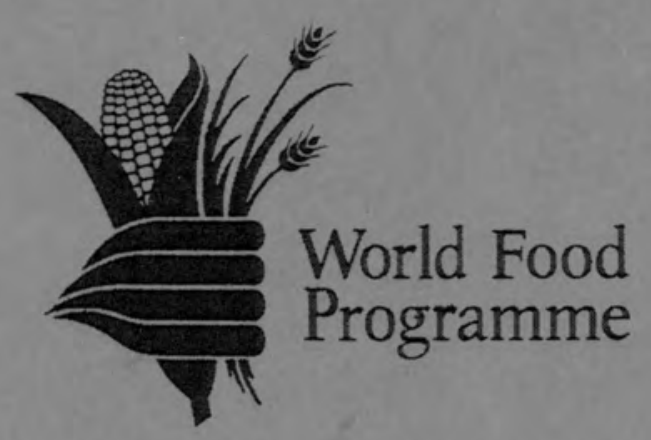




\section{SITUATION REPORT NO. 3}

\section{OCTOBER 1995}

Assistance to refugees,

returnees, displaced persons, and other vulnerable groups

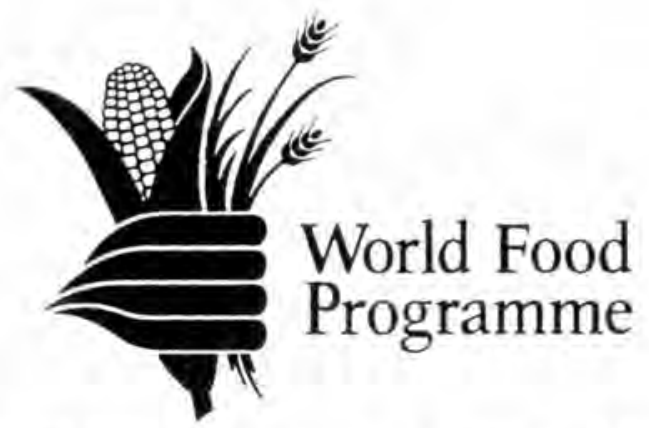

The Food Aid Organization of the United Nations 
The situation in Afghanistan continues to present a significant challenge. The political crisis that began years ago and dominated world attention remains unresolved, although it has long ago slipped from major media attention, now drawn to other humanitarian emergencies in Africa, Eastern Europe and in the newly independent states. Meanwhile, the suffering of the Afghan people continues and the humanitarian crisis intensifies around Kabul and in other isolated areas of the country as factional fighting resumes. In addition to relief assistance, rehabilitation activities through community-based projects, in areas of the country which are peaceful, are being persued, representing about $60 \%$ of total WFP resources in Afghanistan.

The United Nations, through the special representative of the Secretary General, Ambassador Mestiri, has attempted to broker peace accords among the warring factions and assist in the formation of a transitional representational government. These efforts, however, have met with limited success.

Food aid channeled through the World Food Programme represents a most significant contribution to various relief and rehabilitation activities. WFP is now the single largest source of assistance for relief and rehabilitation inside Afghanistan. Food assistance programmes are implemented in collaboration with sister UN agencies and are carried out by both international NGOs as well as by national NGOs. The level and volume of WFP food assistance along the relief to development continutum has been increasing over the years. The 1995 programme is valued at roughly USS 69 million, while the forecasted budget for 1996 is almost US\$ 75 million. WFP assistance directly benefits nearly 2 million Afghans throughout the country.

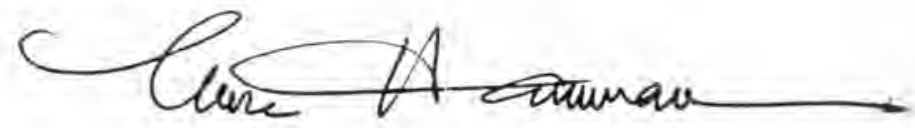

Mona Hammam

Regional Manager

Bureau for the Mediterranean, Middle East, Eastern Europe \& CIS 
World Food Programme

The designations employed and the presentation of material in this situation report do not imply the expression of any opinion whatsoever on the part of the World Food Programme concerning the legal status of any country, territory, city or area or of its authorities, or concerning the delimitation of its frontiers or boundaries. 


\section{TABLE OF CONTENTS}

TABLE OF CONTENTS

INTRODUCTION

OVERVIEW OF THE POLITCALIMILITARY CONTEXT ............................. 6

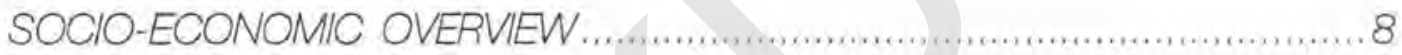

FOOD PRODUCTION AND AVAILABILITY $\ldots \ldots \ldots \ldots \ldots \ldots \ldots \ldots \ldots$

1995 WFP PROGRAMME

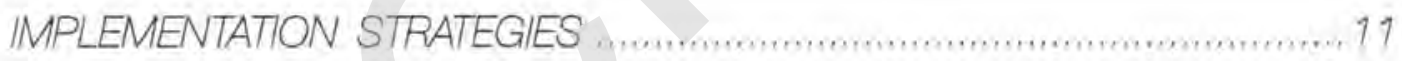

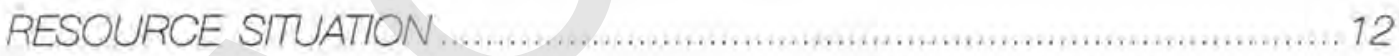

OVERAL DONOR RESOURCE COMMITMENTS ……................ 15

SALENT FEATURES OF THE WFP PROGRAMME

BOX: WPPIUNHCR/DONOR 1995 FOOD ASSESMENT MISSION ...... 18

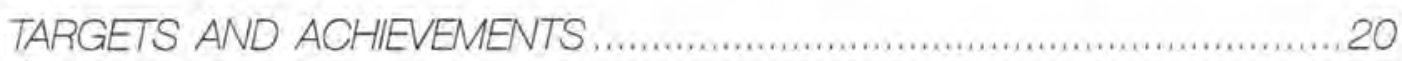

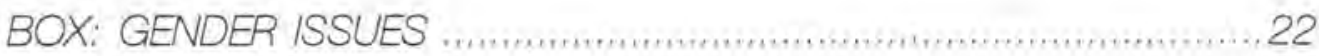

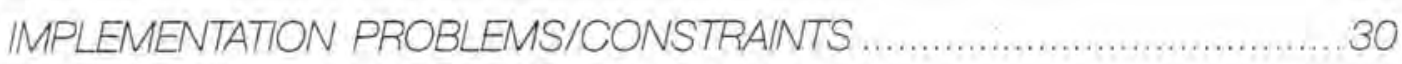

STRATEGY FOR THE SECOND HALF OF 1995

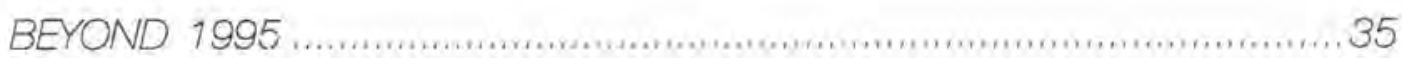


World Food Programme

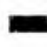

t. 
Afghanistan is a landlocked The country consists of 32 Afghanistan is among the least Country at the junction of three provinces, 298 districts and developed countries in the strategic regions in Asia. The 35,255 villages, with a total world. It has been devastated by country borders the former So- population of 16.9 million 16 years of war, during which viet Union in the north, China (UNIDATA 1990) in a land time millions of Afghans in the northeast, Pakistan in the area of 625,200 square sought refuge in Iran and Paksouth and east and Iran in the kilometers. istan.

west.

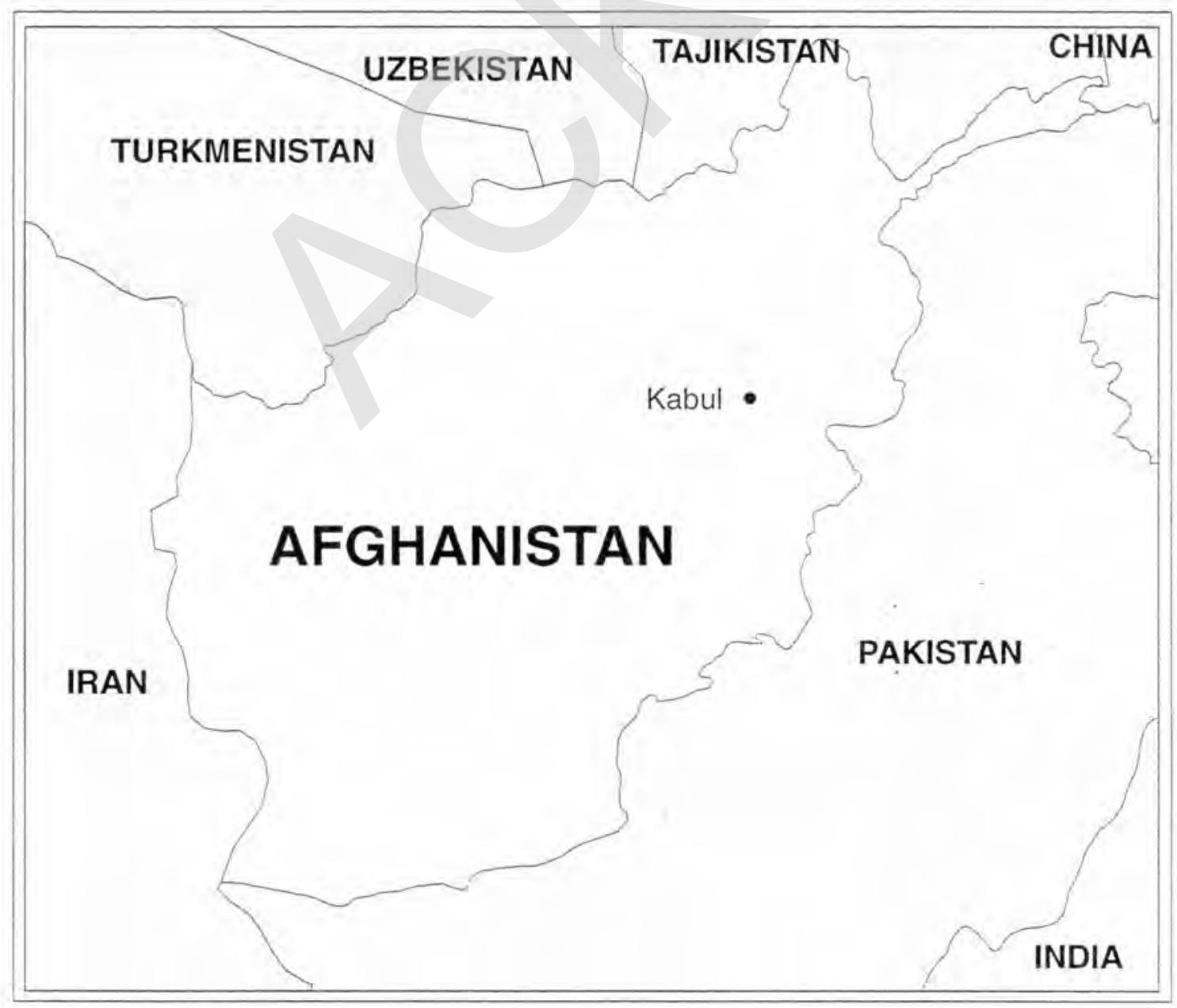




\section{OVERVIEW of the POLITICAL/MILITARY CONTEXT}

JANUARY - JUNE 1995 Kabul, as they confronted proRabbani forces. The displacement

Fighting in different parts of the country continued during the reporting period, with heavy fighting in Kabul, Khost, Bamyan and along the Salang highway. This trend was triggered, in early March 1995 , by the rapid territorial gains of the Talibans, an indigenous Islamic student movement, and the continuation of the struggle for power among Afghan warlords. This development during the first half of 1995 drastically altered the political and military scene of the Afghan crisis and kept the UN peace negotiation efforts searching for a new mechanism to match the emerging, altered realities.

By early March 1995, the Talibans controlled one third of the country. However, later in the month, they faced their first major setback at the outskirts of of a key warlord, Gulbuddin Hekmatyar, from his stronghold at Charasyab by the Talibans in March 1995 and the ensuing capture of Charasyab by pro-Rabbani forces, changed the political and military equation in the struggle for the capital, Kabul. This military gain by proRabbani forces protected Kabul from rocketing range and brought tranquillity to the residents of the city for the first time in fifteen months, enabling displaced families residing in camps in Jalalabad and other areas to return to their original neighborhoods in Kabul. Although relative peace has since prevailed in Kabul, it remains a tenuous peace, vulnerable to challenge. Taliban forces remain poised to re-launch an offensive to take Kabul at any time.

Following the capture of Charasyab from the Talibans by the Rahbani/Masood Forces, re- newed fighting erupted in the west of Afghanistan between the Talibans and the forces of Ishmael Khan, a pro-Rabbani ally, to capture the strategic Shindand air base in Farah province.

Sporadic fighting flared between Ishmael Khan's forces and the National Islamic Movement (NIMA) which controls northem Afghanistan, in close collaboration with Hezb-e-Islami in the east of Herat at Morghab district in Badghis province. The fighting in the west of Afghanistan resulted in the closure of the Herat - Kandahar highway for two months and destruction of a strategic bridge in the east of Herat which links it to the north. Although periodic skirmishes continued after April 1995, a cease-fire between the Talibans and the Ishmael Khan forces was concluded in June, 
leading to the limited opening of the Herat - Kandahar highway.

While the Talibans were engaged in fighting on various fronts, areas under their control in the south remained relatively peaceful. The prevailing peaceful situation in the south of Afghanistan was closely monitored by UN agencies and international organizations. Beginning in March 1995, six UN agencies and a number of international organizations were able to reestablish their presence in Kandahar.

The northern region of Afghanistan also continued to be relatively peaceful, although small to medium scale skirmishes between rival factions in various provirces were reported. The breakdown of negotiations between the Jamiat party and NIMA led to renewed fighting in the Salang area, with both parties claiming victories.
Fighting was reported in Bamyan province between the Jamiat party and Hezbi-wahdat, with Bamyan city reportedly taken over by the Jamiat party in June 1995. Intense military activities were reported in Kunduz province in the early part of the year, but gradually gave way to a semblance of peace. The situation in Kunduz province remains unpredictable, with the recentselective bombing of military targets near Kunduz by NIMA forces.

In eastern Afghanistan, the security situation remained calm during the reporting period. The Jalalabad shura, with representatives from seven political parties, managed to maintain their neutrality by avoiding direct alliance with the major warlords locked in the power struggle for the country.

The UN peace initiative of Ambassador Mestiri continued dur- ing the reporting period. However, efforts to persuade Rabbani to relinquish power in order to facilitate the formation of a representative government in Kabul faced serious constraints. The new Rabbani Peace Plan, which is not fully in line with the mechanism proposed by the UN, combined with the recent military gains by the Kabul government, further complicated the Mestiri-led process. Although the UN peace effort continued, the mono-ethnic composition of the current Kabul government remains a serious obstacle. There are indications that the non-Tajik opposition are trying to set up a parallel national government to be possibly. headquartered in Jalalabad. 


\section{SOCIO ECONOMIC OVERVIEW}

According to the UNDP Human development index, Afghanistan is the third poorest country in the world and the only non-African nation among the bottom twelve on the list. The continued devastation of rural micro economies and the resultant human suffering are reflected in an increasingly high number of vulnerable persons and a high malnutrition rate in rural and urban areas among children under five years. Only a small percentage of Afghans have ac- cess to safe drinking water, sanitation, food, health services and education, although most parts of the country continued to be peaceful.

Living conditions reflect a growing phenomenon of urban poverty, corresponding to the high rate of migration from rural to urban areas as basic rural micro economies, devastated by 16 years of war, fall short of a basic sustenance level for survival.

The high number of returnees and internally displaced persons concentrated in urban areas are putting immense pressure on fragile urban economies, social infrastructure and services, which are already inadequate and poorly endowed.

According to UNHCR statistics, 1,500 people, on average, were returning daily to Kabul, with a cumulative estimated return of 125,657 displaced persons between 6th April 1995 and 29th June 1995

\section{FOOD PRODUCTION AND AVAILABILITY}

FAO statistics indicate that Afghanistan in 1995 has an estimated food deficit of $1.2 \mathrm{mil}$ lion tons of cereals, although food production this year is estimated to be better than in previous years.

Limited availability, inad. equate access and high prices of food commodities continue to affect the food security of the urban poor and vulnerable groups in the country. The agrarian economy of Afghanistan continues to be characterized by extensive tracts of food deficit and marginal food produc- from relatively surplus producing areas as a result of the devas- ing areas to densely populated tation of the rural production system, the lack of agricultural inputs and large-scale migration of skilled farm labour to urban areas.

Regional variations in food production and access to food by the poor and vulnerable groups underscore the differences in regional vulnerability in Afghanistan.

Due to poor road conditions, high fuel prices and political instability in various parts of the country, the movement of food commodities urban centers remains a major problem. The net effect is high prices of basic food commodities above the affordable level for the poor and vulnerable groups and periodic shortages of basic food commodities in urban centers. 


\section{WFP PROGRAMME}

The objective of the 1995 food fice, while maintaining emeraid programme for Afghanistan is gency relief as a priority:

to provide humanitarian reliefl emergency assistance to internally displaced persons and support people-oriented and community-based rehabilitation activities, with an approved resourcé commitment of 172,500 tons of food aid, targeting $1,850,000$ beneficiaries (see box below).

\section{UNOCHA}

Under the UN Consolidated Appeal, WFP also sought an additional 78,335 tons of food aid to meet the needs of the increased number of internally displaced persons resulting from the Kabul emergency, as these were not covered by WFP's regular programme.

In view of the challenges of the 1995 programme, entailing a transitional phase from relief to rehabilitation, the following corporate goals were adopted by the Afghanistan Country Of-
- Emphasis on improving the quality of projects undertaken.

- Increase in rehabilitation activities in peaceful areas through larger-scale umbrella projects and expansion of cooperation with functioning government departments.

Increase in inter-agency (UN) cooperation projects for joint implementation.

Systematization of WFP's programming strategies for Afghanistan and the incorporation of the UNIL OG logistics unit into the WFP/Afghanistan Country Office responsibility from WFP/Pakistan.

- Contribute to strengthening the peace process in Afghanistan.

To ensure better quality projects and better resource programming, priority food aid interventions were targeted to areas of food deficit, IDPs/refugee concentration, poppy substitution potential, strategic viability for WFP transport activities, prevailing peace with functioning government departments as well as deprived war-affected areas. where year-round endemic unemployment and proneness to disaster persist.

Quarterly programming of resources was adopted by the Country Office, with the forllowing monitoring mechanisms to assure proper targeting and project quality:

A self-monitoring mechanism through sign boards placed at project sites, with information on WFP funding levels and entitlements of WFP beneficiaries.

Beneficiary contact monitoring.

- Structured field visits from sub-offices.

Structured field visits from the Country Office,

\begin{tabular}{|l|r|c|}
\hline Activities & $\begin{array}{r}\text { Approved CFA } \\
\text { Allocation (in MT) }\end{array}$ & Percentagge \\
\hline \hline Food For Work (8.6 million man/days) & 60,000 & $35 \%$ \\
Intemally Displaced (IDPs) & 38,851 & $23 \%$ \\
Vulnerable Groups & 10,874 & $6 \%$ \\
Urban Poor (via Bakery projects) & 18,000 & $10 \%$ \\
Relief Emergency feeding & 21,775 & $12 \%$ \\
Monetization & 25,000 & $14 \%$ \\
\hline
\end{tabular}


- Use of NGOs with umbrella function', contracted monitors and volunteer collaborators.

- Monitoring by partner UN agencies.

- Periodic tripartite review in the field.

- Follow up on post-monitoring measures.

The following projects were planned against the 1995 programme for Afghanistan:
Bakery projects in urban ar- for training) and income generateas, targeting the urban poor and ing projects.

vulnerable groups in Herat, Mazar, Kandahar, Faizabad and Jalalabad.

- Road rehabilitation, through food-for-work public works schemes, to improve access.

- Care and maintenance food assistance for internally displaced persons in camps.

- Provision of integration and resettlement assistance for returnees from Iran and Pakistan.

- Integration assistance to Kabuli displaced.

- Local food purchase in areas jointly determined with FAO.

- Youth and women's projects through vocational training (food

\section{FOOD ALLOCATION}

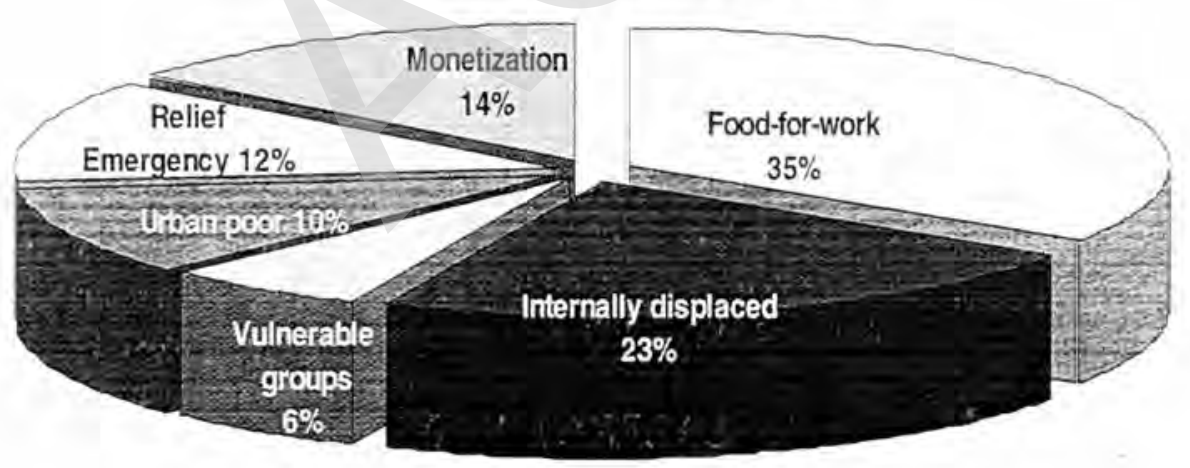

\footnotetext{
The "umbrella" project concept is one in which one large NGO contracts with WFP for undertaking overall responsibility for project implementation in either one geographical area or under one sector. The umbrefla NGO may then sub-contract other NGOs, including national NGOs, for project execution. The umbrella NGO undertakes certain responsibilities vis-à-vis WFP, such as monitoring and reporting on all activities under the WFP approved umbrella operation.
} 


\section{IMPLEMENTATION STRATEGIES}

Core implementation strategies of the 1995 programme during the reporting period included the following:

\section{FOOD-FOR-WORK PROJECTS (FFW)}

Food-for-work projects formed an integral part of the global United Nations effort to facilitate socio-economic recovery in Afghanistan and to assist in the establishment of longerterm peace through broad, people-oriented and communitybased rehabilitation activities. The main programmatic focus of food-for-work projects is the rehabilitation of rural infrastructures that have immediate income generating effect, in order to facilitate the reintegration and resettlement of returning Afghan refugees and the process of sncioeconomic recovery in the comtry.

\section{VULNERABLE GROUP FEEDING PROJECTS (VGF)}

Vulnerable group feeding projects target mainly the urban poor and displaced persons. An important element of the vulnerable group component is the bak- ery project. Through this scheme, wheat is provided to urban bakeries at low cost to bake bread and sell to identified urban poor and vulnerable groups at highly subsidized prices. Funds generated from the sales are plugged back into other community rehabilitation works. The bakeries project is identified as a potential source for establishing womenmanaged enterprises.

INSTITUTIONAL FEEDING PROJECTS (FI)

Institutional feeding projects target hospitals, clinics, orphanages and homes for the disabled and other institutions that cater for the needs of the disadvantaged groups, where the local authorities, NGOs and/or private associations can assure adequate operational responsibilities.

\section{EMERGENCY ASSISTANCE}

Emergency assistance targets persons in areas of the country considered vulnerable in terms of food production/supply and accessibility. Beneficiaries includ victims of floods, landslides and earthquakes to whom food aid is distributed as immediate relief until it becomes possible to undertake regular food-for-work projects for reconstruction and to mitigate further disasters.

\section{GENERATED FUNDS}

Local cash resources for the purchase of non-food items to support food-for-work projects, and to meet part of the operational and administrative costs of NGO implementing partners, are generated through limited, closed monetization within projects and open monetization in food deficit areas. Part of the proceeds are occasionally utilized for local purchase of food in surplus production areas and payment of its transportation to highly inaccessible areas, where transport costs are high. The bakery projects also generate some cush resources which are plow:d back into the project or to support rehabilitation projects. While commodity availability remains below the planned level, monetization outside the bakery projects will not likely be carried out in the 1996 phase of the PRO. 


\section{RESOURCE SITUATION OF THE 1995 PROGRAMME}

Resources for the 1995 programme were expected from two sources: the regular protracted refugee operation (PRO) endorsed by the CFA in December 1994 , for a total of 172,500 tons of food aid, and the United Nations Consolidated Appeal for Afghanistan (UNOCHA) for an additional 78,335 tons of food aid to meet the requirements for the increased caseload of internally displaced persons in Jalalabad and for the Kabul emergency operations.

As at end of June 1995, 132,688 tons of food aid has been pledged by donors and received for the Afghanistan programme. This reveals a shortfall of 39,812 tons of food aid against the 1995 regular CFA approved programme, but a shortfall of 107,000 tons of food aid when the separate UNOCHA appeal is included.

There are additional, but unconfirmed, donor pledges, amounting to a total of 62,500 tons of food aid against the regular programme. As the IDP requirements receive priority allocation, the available resources will not likely be sufficient to meet the to also meet the infrastructural rehabilitation targets set for 1995.

Reviewing the pledges against the
1995 programme requirement, along with expected future arrivals, actual availability of resources for 1995 is estimated at around 150,000 tons of food commodities.

The major problems affecting the 1995 programme are the delayed arrivals of announced pledges and pledges not made available at the required destinations in Afghanistan. Most of the 1995 food allotments received this year have been through the southern pipeline (Pakistan). This has led to the serious under-supply of the northern pipeline (from the Baltic ports supplying north and western Afghanistan), hampering WFP's ability to maintain an optimum level of programming in these two regions.

To cope with this problem, the country office has undertaken the following actions:

\section{ADJUSTMENT OF QUARTERLY FOOD AID REQUIREMENT PLANS}

Quarterly food aid requirement plans of all sub-offices have been adjusted to reflect the estimated availability of resources to the end of the year i.e., 150,000 tons of food aid.
This is done through quarterly allocations to firm and flexible programming plans by all sub-offices.

\section{INITIATION OF SWAP ARRANGEMENTS WITH PRIVATE TRADERS}

In view of the arrival of most of the 1995 commodity resources via the southern pipeline, swap arrangements have been undertaken in an attempt to provide our northem and western Afghanistan sub-office areas with at least the minimal resources to maintain essential food aid activities.

For the Herat sub-office, a swap arrangement involving the supply by private traders of 6,000 MT of wheat in Herat is ongoing and will be replenished from WFP stocks in Quetta and Peshawar. An additional swap of $3,000 \mathrm{MT}$ of wheat is programmed through private traders for replenishment of stocks in Mazar, in addition to an ongoing swap of excess oil and sugar for local wheat. Unless the stocks released from Peshawar and Quetta are replenished with new shipments, the high priority programming in southern areas will soon face the same resource problems as Mazar and Herat. 


\section{Summary Overview of Food Requirements and Pledges}

\section{Jannuary - December 1995}

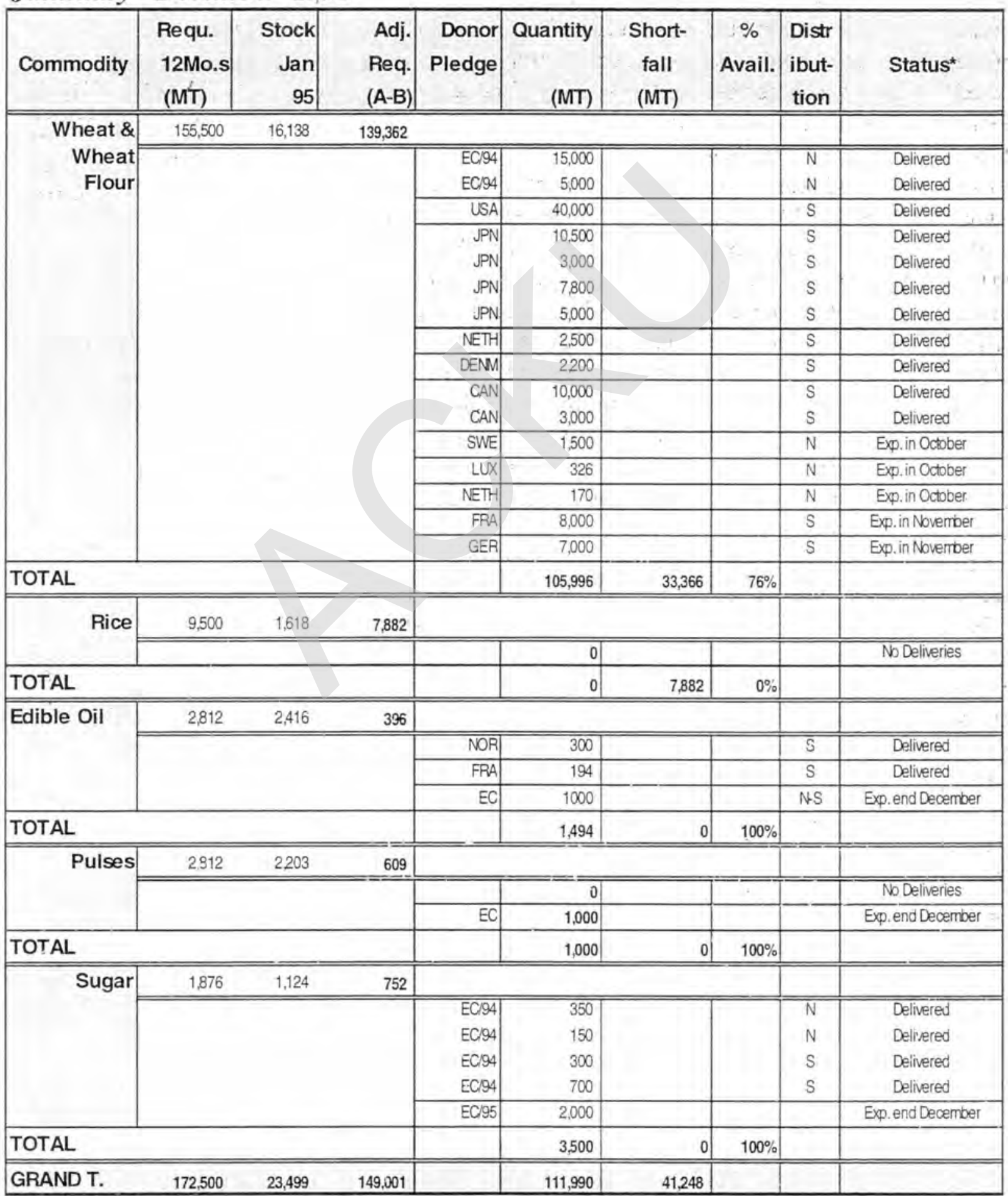


With the unpredictable political situation in Afghanistan and periodic fighting along the main routes inside the country, coupled with the high toll requested by commanders or warlords, most private traders are somewhat reluctant to undertake these swap arrangements on behalf of the Programme. Due to the bureaucratic procedures involved in getting permits to transport wheat from Pakistan to Herat via Iran, most transporters from Pakistan are not willing to tender for such transportation contracts.

\section{REGIONAL from Kazakstan at approximately PURCHASE OF half the price of wheat purchased WHEAT in Europe.}

Recent investigations by a WFP

Regional purchase of wheat was an option identified by the Country Office to replenish stocks in Herat and Mazar as quickly as possible at the lowest cost. Unfortunately, cash resources from donors for these transactions have been limited and the initial regional wheat purchase in Kazakhstan for Badakshan Province in Afghanistan encountered some logistics problems. Available information from the Country Office indicates that wheat can be purchased
Headquarters/Country Office mission to Kazakhstan determined that the final cost of a ton of wheat is between USD 150 180/MT free on rail Termez, while a similar amount from Europe will cost about USD 320/ MT free on rail Termez. Besides the economies of scale inherent in pursuing regional purchases, the hard Kazak wheat tends to be more attractive to Afghans than the soft wheat procured from Europe.

\section{TENTATIVE / PROPOSED PLEDGES FOR AFGHANISTAN}

\section{5 - FOOD COMMODITIES (MT)}

\section{(Not Included in the Pipeline)}

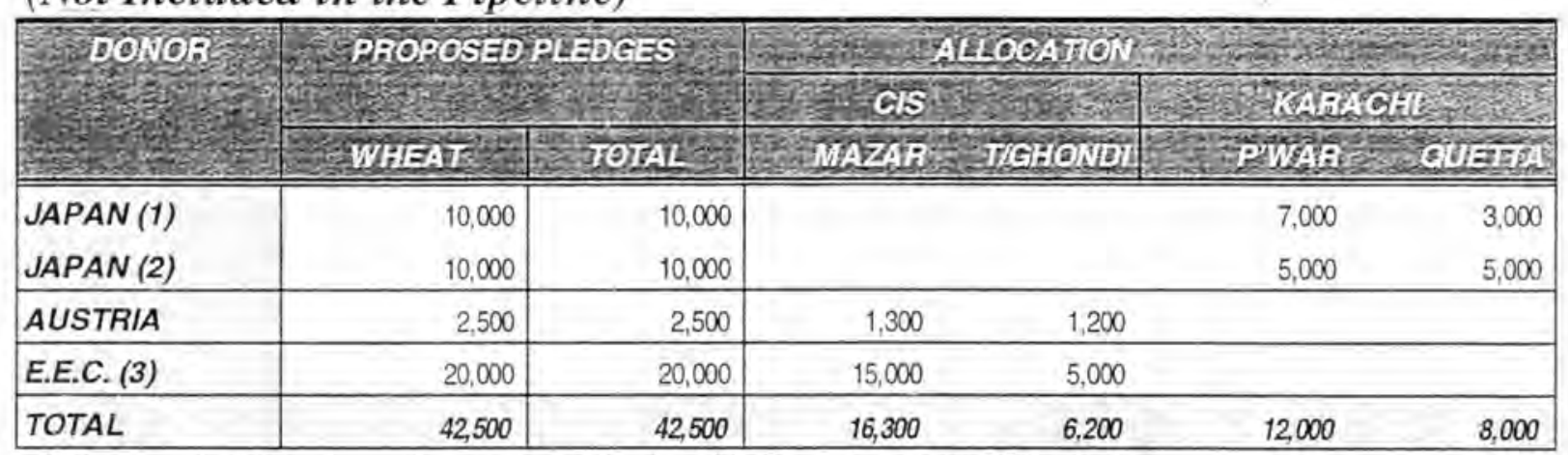

(1) Proposed 1995 release from special funds - (2) Tentative 1995 PRO pledge

(3) Proposed 1995 pledge 
Food and cash resources for the 1995 WFP Afghanistan programme are allocated by donors through WFP's governing body on an annual basis. WFP expects that the total estimated requirements can usually be met through this mechanism, although there are periods during the year when it would appear that there may be a shortfall of available resources against expected requirements.

A variety of donors have responded favourably to the food and cash requirements of the 1995 Afghanistan programme. (See the accompanying bar chart on page 14). However, some pledges for 1995 have yet to be confirmed and it would now appear that about 150,000 metric tons of food will be delivered against the tocal requirement of 172,500 tons $(87 \%)$. In respect of cash pledges, only slightly more than half the requirements have been resourced. As of September 1995, there remains a shortfall of US\$ 1.4 million against an overall annual budget requirement of US $\$ 3.3$ million for monitoring and logistics support costs.

\begin{tabular}{|c|c|c|c|c|}
\hline \multicolumn{5}{|c|}{ Donor Contributions through WFP in MT and US\$ } \\
\hline Donor & Volume & ED: & Commodits & Valoe \\
\hline 6 & (Mi) & & 128 & (USS) \\
\hline \multirow[t]{4}{*}{ Germany } & 2,786 & MZR & Wheat & $1,168,727$ \\
\hline & 1,481 & MZR & Wheat & 621,279 \\
\hline & 733 & MZR & Wheat & 307,494 \\
\hline & 2,000 & HRA & Wheat & 837,000 \\
\hline S/total & 7,000 & & & $2,934,500$ \\
\hline \multirow[t]{2}{*}{ France } & 8,000 & JAL & Wheat & $2,728,000$ \\
\hline & 250 & JAL & Vegetable Oil & 242,500 \\
\hline S/total & 8,250 & & & $2,970,500$ \\
\hline \multirow[t]{3}{*}{ Netherlands } & 2,500 & KNR & Wheat & 669,875 \\
\hline & 170 & FAI & Wheat & 44,200 \\
\hline & 600 & $|\mathrm{~TB}|$ & Wheat & 155,800 \\
\hline S/total & 3,270 & & & 869,875 \\
\hline Denmark & 2,200 & JAL & Wheat & 589,490 \\
\hline S/total & 2,200 & & & 589,490 \\
\hline Sweden & 1,500 & FAl & Wheat & 390,000 \\
\hline S/total & 1,500 & & & 390,000 \\
\hline \multirow[t]{4}{*}{ Japan } & 11,000 & JAL & Wheat & $3,038,750$ \\
\hline & 2,500 & KNR & Wheat & 690,625 \\
\hline & 5,000 & JAL & Wheat & $1,470,000$ \\
\hline & 7,800 & JAL & Wheat & $2,293,200$ \\
\hline S/total & 26,300 & & & $7,492,575$ \\
\hline \multirow[t]{2}{*}{ EEC } & 5,000 & HRAIMZR & Wheat Four & $1,900,000$ \\
\hline & 15,000 & HRAMIMR & Wheat & $4,800,000$ \\
\hline S/total & 20,000 & & & $6,700,000$ \\
\hline USA & 40,000 & JAL & Wheat & $12,400,000$ \\
\hline S/total & 40,000 & & & $12,400,000$ \\
\hline Norway & 300 & JAL & Edible Fat & 336,828 \\
\hline S/total & 300 & & & 336,828 \\
\hline Canada & 13,000 & JAL/KNR. & Wheat & $4,285,714$ \\
\hline S/total & 13,000 & & & $4,285,71,4$ \\
\hline Luxembourg & 326 & FAl & Wheat & 86,608 \\
\hline S/total & 326 & & & 86,608 \\
\hline \multirow[t]{2}{*}{ Austria } & 1,300 & KAB & Wheat & 238,199 \\
\hline & 1,200 & $K A B$ & Wheat & 225,000 \\
\hline S/total & 2,500 & & & 463,199 \\
\hline TOIALE & 9124696 & & & 39519289 \\
\hline
\end{tabular}

OTHER DONOR CONTRIBUTIONS (in Kind)

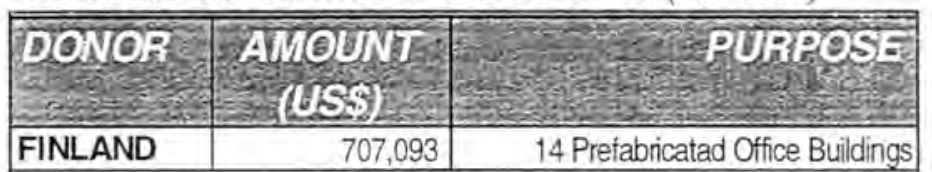


Monitoring and Logistics Costs

\begin{tabular}{|ll|}
\hline Country & Afghanistan \\
Project No. & 5086.02 \\
Requirements (US\$) & $3,280,700$ \\
Duration: & January to December 1995 \\
Caseload: & $1,850,000$ \\
TSH: & US $\$ 50$ per metric ton \\
M \& L: & US\$19 per ton \\
\hline
\end{tabular}

Contributions Received

\begin{tabular}{|c|c|c|c|}
\hline Donor & $\begin{array}{c}\text { Confirmed } \\
\text { Pledge US\$ }\end{array}$ & Shortfall & REMARKS \\
\hline Denmark & 116,294 & & 1994 funds \\
\hline Sweden(94) & 388,099 & & 1994 funds \\
\hline Netherlands & 100,000 & & 1995 funds \\
\hline Sweden(3M) & 410,959 & & SEK6M, 50\% SEO \& 50\% Food Cost \\
\hline Norway & 318,471 & & Kr2m for SEO, possibly transport cost \\
\hline Netherlands & 250,000 & & MEMO $1 / 6 / 95$, \\
\hline Sweden & 200,000 & & SWEDEN 1995 \\
\hline TOTAL & $1,783,823$ & $1,496,877$ & \\
\hline
\end{tabular}

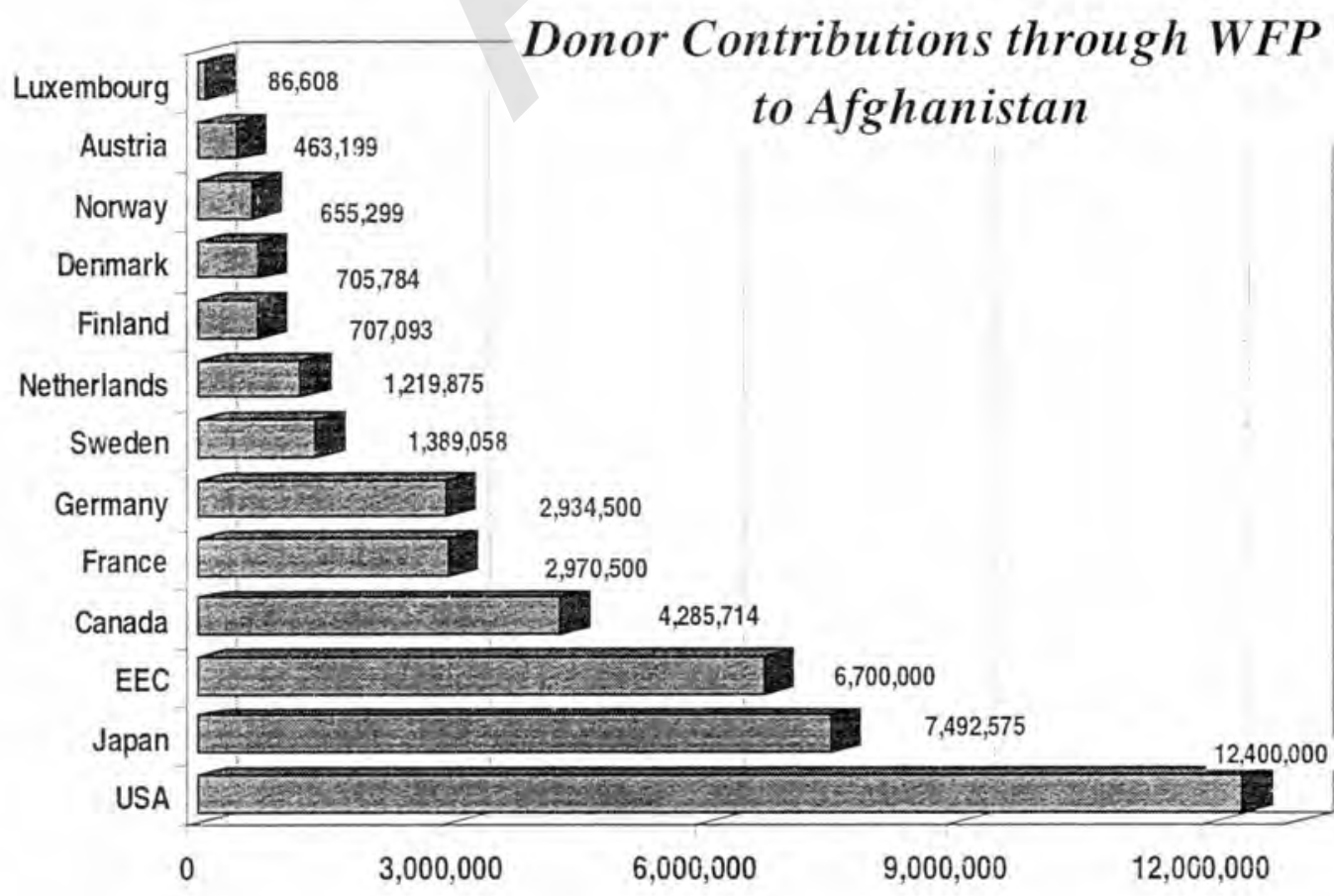




\section{SALIENT FEATURES OF THE WFP PROGRAMME}

\section{RELIEF TO REHABILITATION}

WFP is the largest single UN source of aid to Afghanistan, operating from seven sub-offices within the country, with three major logistics bases in Uzbekistan and Pakistan. The logistics network of the programme also caters to the logistics needs of sister UN agencies and NGOs working in Afghanistan. In responding to the needs of the poor and food insecure, WFP restores hope as they engage in the rehabilitation of their devastated economy in the process of socioeconomic recovery. Thus, food aid in Afghanistan provides both the means for survival for the hungry and poor and at the same time can "kick start" rural rehabilitation in peaceful areas.

The food aid programme for Afghanistan spans the continuum from emergency relief to rehabilitation, with some proto-type development strategies. It adapts itself to the regional variations in vulnerability, preventing hunger and starvation.

Part of the emergency component resources are used for rehabilitating infrastructure, through food-for-work projects, with the objective of promoting local initiatives and self-reliance as well as supporting poverty alleviation activities in keeping with the Afghan peoples' sense of dignity. An example of this dynamic approach is reflected in the emergency assistance provided to internally displaced persons. This includes a strategy of gradualiy phasing down the distribution of free food rations in favor of productive food-for-work projects and human resources rehabilitation to reduce dependency on food aid.

In view of the challenges posed by the continuum, programming is directed preferentially to peaceful areas, with an in-built institution-building focus in respect of functioning government departments. Closely linked with this approach is increased cooperation with NGO implementing partners under umbrella projects, providing training opportunities for many as yet inexperienced local NGOs in partnership with an international NGO, or a functioning government department.

Cooperation with sister UN agencies for joint implementation is also given high priority. This translates into better quality projects with the comparative advantage of access to complementary nonfood resources and technical sup- port. To ensure that the value of a dollar received from donors goes a long way to meet the needs of Afghans, inter-agency collaboration during the reporting period has led to the preparation of a draft memorandum of understanding with sister UN agencies, such as FAO, and co-funding of food aid projects with UNHCR, WHO, UNDCP. UNICEF, UNOPS, and UNCHS.

SPECIAL RELATIONSHIP WITH NGO'S

In the absence of functioning goverument departments in most areas and continued political instability, implementation of WFP food assisted projects in Afghanistan is carried out in collaboration with approximately 31 international NGOs and 113 national NGOs. In its collaboration with national $\mathrm{T} G \mathrm{G}$, WFP also covers approximately 10 percent of their adminis ative costs, generally, in the form of wheat. Donor $^{2}$ NGOs do not receive administrative support from WFP.

Projects implemented in partnership with NGOs are normally based on requests received from local communities. The NGOs prepare project proposals and submit them to WFP for review

\footnotetext{
2 "Donor NGOs" mean those NGOs that have a solid financial foundation and usually receive financial contributions from a wide variety of sources that enables project implementation.
} 
and appraisal. If found appropriate for WFP assistance, the project proposals are approved. Through this mechanism, WFP collaborates with NGOs in a wide variety of projects which include bakery projects for vuinerable groups, food-for-work projects, including irrigation networks and roads, rehabilitation of hospitals, construction of schools etc. About 60 percent of the total programme portfolio is implemented in partnership with NGOs.
In addition to acting as implementation partners, NGOs also assist WFP in monitoring projects. For example, ACBAR, a coordinating body of NGOs, is responsible for monitoring the Kabul bakery project.

\section{WFPNNHCR/DONOR FOOD ASSESSMENT MISSION TOPAKISTAN AND AFGHANISTAN}

(21 April-9May 1995)

TheannualWFP/HCR/Donorfood assessmentmission to Pakistanand Afghanistan took placefrom 21 Aprilto 9 May 1995 . The 1995 mission re-validated the planned phase out of care and maintenance food ration distribution to registered Afghan refugees in Pakistan, as recommended by the 1994WFPNNHCR/Donor Food Assessment Mission. This revalidation is the logical and natural conclusion the protracted refugee operation, as the refugee beneficiaries havenows attained a high level of self-reliance. Periodic reductions of food basket contentand rations, implemented on a gradual and systematic basis over recentyears, havenotadversely affected the health and nutritional status of the beneficiary population. In fact, the December 1994 and March/April1995 nutritional surveys reflecta continued improvement of the Afghan refugee population's nutritional status, and at levels which are better than of the local rural Pakistani population. Socio-economic datapresented to the mission from recent surveys also indicate an ever-increasing level of self-reliance amongst the Afghans in Pakistan.

The 1995WFPNNHCR/DonorFood/AssessmentMissionto Pakistan and Afghanistanhas focused on relief and rehabilitation food assistance programmes inside Afghanistan. Thisemphasis is consistent with the approach of other UNagencies and donors to support rehabilitationactivities inside Afghanistan, to intensify the UN activities in the safe areas of Afghanistan, so as to create conditions conducive for the retum of refugees and displaced persons to their places of origin.

(Continues...) 
Having had the opportunity to observeand review the various ongoing activities supported underthe Afghanistan PRO 5086102(1995programme) in eastem, southem, northem and westem Afghanistan, as well as the recently expanded food assistance programme in Kabul, the mission has observed significantregional differences in the overall programme.The ongoing Afghanistan PRO contains componentsall along the relief -rehabilitation-development continuum, and there seems to be a direct correlation between the relative peace and stability of a region and the advanced level of activities along the continuum towards reconstruction in those areas. In fact, while addressing immediate humanitarian relief concems, most projects have simultaneously madesignificant contributions to the rehabilitation of essential nural and urban infrastructures.

WFP food commodities represent a most significant resource in Afghanistan today. Food is being used for (a) relief feeding of the intemally displaced (IDPs), (b) vuinerable groups and the urban poor, (c) labor intensive food-for-work (FFW) rehabilitation activities, (d) some food-for-training (FFT) and (e) urban bakeries.In many cases,WFP food under the FFW andFFT components represents an important catalyst for assistance provided by other organizations, including sister agencies of the UN (UNHCR, UNICEF, UNDP/OPS, UNCHS,WHO, etc.), international organizations, intemational non-govemmental organizations (NGOs) and national organizations or associations. In someareas, local government capacity is also being enhanced through mutually supportive collaboration in the implementation of the food assistance programme.

Despitecertain difficultiesencountered in working towards rehabilitation inside Afghanistan, the mission has been impressed with the level of cooperation and coordination that does existamong these various partners and the extent to which tangible results have been achieved. Much more needs to be undertaken and can be done if peaceand stability can prevail.

The capacity for expanding theWFP Afghanistan programme, to meet the resettlement and reintegration needs of potentially 700,000 Afghan refugees retuming from neighboring countries this yearcan beenhanced through provision of increased technical, monitoring and logistic resources, in addition to amore dependable and regular supply of CFA approved commodities.

The virtual absence of local technical capacity among the returning population is a limiting factor in the implementation and sustainability of urgently required human resourcerehabilitation projects as well as longer term rehabilitation measures, to which WFPcan makesignificantcontributions. 


\section{TARGETS AND ACHIEVEMENTS}

\section{JANUARY - JUNE 1995}

From January to June 1995 , the country programme had a planned utilization target of 86,200 MT of food aid for emergency assistance and rehabilitation activities in Afghanistan. As at end of June 1995, 53,121 MT of food aid was utilized through the seven sub-offices, reaching 900,000 beneficiaries in the country. This represents 61 percent of the planned achievement target during the reporting period and could have been greater had the food supply situation been better.

A total of 188 projects were completed during the reporting period, while 273 remain ongoing, with an existing approved commitment of $31,330 \mathrm{MT}$, Of the total quantity distributed during the reporting period, 35.5 per- cent were utilized for the feeding of internally displaced persons in camps and Tajik refugees in the north. Another 31.4 percent were distributed through food-forwork projects. These activities support rehabilitation of productive rural and urban infrastructures to facilitate reintegration and resettlement of Afghan returnees in the process of socio-economic recovery in the country. The third largest component of the programme, vulnerable group feeding and institution feeding projects, utilized 28.6 percent of the available food resources.

The bakeries projects were the main mechanism for reaching the urban poor and vulnerable groups, including widows, street children, the disabled, the elderly and orphans. Less than one percent of total resources were utilized for emergency assistance to meet humanitarian needs arising from natural disasters.

The lower-than planned actual utilization during the reporting period was partly due to lack of sufficient resources at certain sub-offices, mostly in the north and west of the country. The low opening stocks in Herat and Mazar sub-offices and the recurrent blockade of the Jalalabad

- Kabul route during the first quarter, affected food delivery to Kabul, and delaying distribution of existing commitments brought forward from 1994, and limiting the initiation of new projects in Herat and Mazar. The bakery project in Herat, targeting 120,000 beneficiaries, began only in February 1995, followed by the bakery project in Jalalabad (150,000 beneficiaries) and Mazar (130,000 beneficiaries) in March and Kandahar $(25,000)$ in April.

\section{Food Distribution by Programme Component (January - June 1995)}

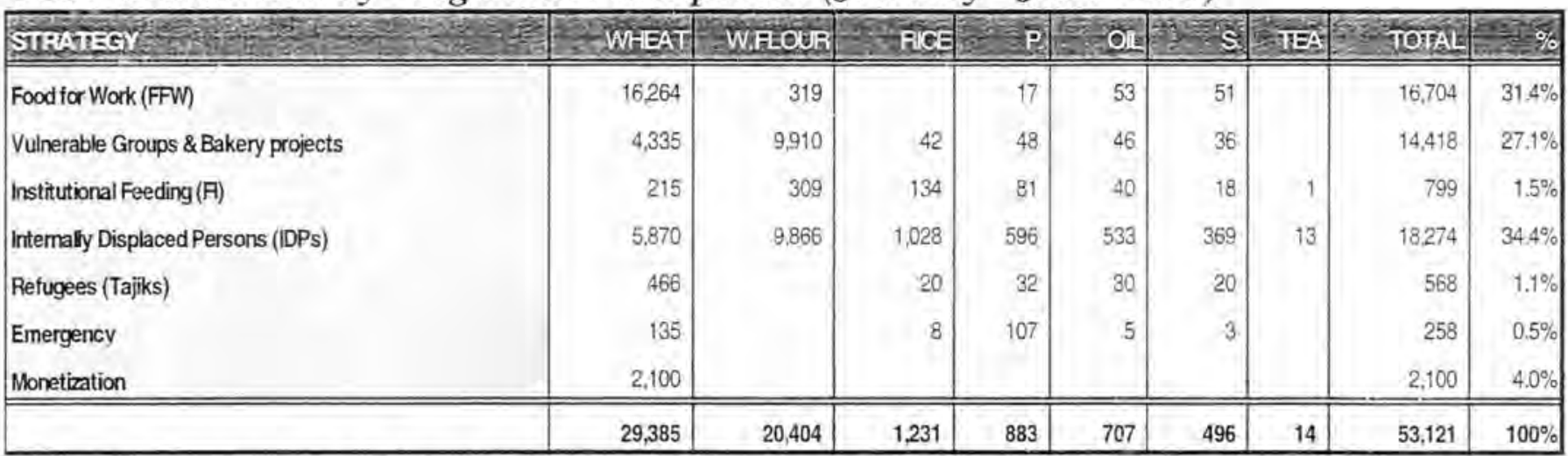

1. Tea is not included in our 1995 PRO allocation.

202 . Monetization is mostly close monetization with in food-for-work projects to provide non-food items: 
CONTRIBUTION TO CORPORATE GOALS OF COUNTRY PROGRAMME SYSTEMATIZATION
OF WFP OPERATION

Systematization of WFP operations in Afghanistan was a major challenge during the reporting period in view of the regional variation in rural and urban poverty in the country, coupled with variations in the extent of devastation caused by the war. To harmonize our systems with the existing realities, the Country Office organized a programming, logistics and finance workshop in February 1995 at the Country Office in Islamabad. The workshop was attended by all Heads of sub offices, including programming, logistics and finance staff. The deliberations drew on experience during the implementation of the 1994 programme, achievements and lessons learned as a basis for the 1995 programme. This was followed by presentation of regional priorities for the 1995 programme, resource allocation and clarification of existing policies on programming of food aid. monetization, project approval, monitoring and management of financial resources.

Although the length of the workshop was found to be insufficient, evaluation by participants indi- cated that the workshop was useful in clarifying programming policies and the challenges of the WFP programme for Afghanistan in general.

Major outputs of the workshop were as follows:

Need to review existing implementing partners, based on past experience and implementation of the umbrella project concept to reduce the number of direct implementing partners

Adoption and implementation of quarterly programme planning of resources.

a Identification of regional priorities on a quarterly basis.

- Need for increasing interagency collaboration projects, in view of its comparative advantage to improve the quality of projects undertaken.

- Need for increasing cooperation with functioning government departments with an institution-building focus. This process led to the formulation and adoption of the "peaceful areas" policy which promoted an increase in cooperation with functioning government departments

- Clarification of the basic principles of monetization and strategies for effective monitoring of projects in Afghanistan.

- Clarification of the project approyal process.

\section{EMPHASIS ON \\ IMPROVING THE QUALITY OF PROJECTS UNDERTAKEN}

To counteract dependency among food aid recipients and in order to improve the quality of projects undertaken, the following actions were implemented with regard to the country programme during the reporting period:

\section{- Participatory project as-} sessment, involving beneficiaries and implementing partners, was followed up at all sub-offices.

- Quarterly update of regional priorities and resource requirement plans were prepared by all sub-offices.

\section{- Emphasis on local contri-} butions and counterpart contributions, as a preliminary condition for WFP assistance, was enforced at all sub-offices.

Screening of implementing partners based on past experience. This activity led to screening out some implementing partners at various sub-offices, based upon their record of performance.

Inclusion of literacy classes in vocational training projects.

- Introduction of a two-tier pricing system for the bakery 
projects to reduce dependency on food aid and generate local resources for reinvestment in productive rehabilitation activities.

\section{- Monitoring of projects through NGO partners, sister UN agencies and regular project vis-}

its from sub-offices, reinforced with periodic field visits from the Country Office staff.

Increase in inter-agency
collaboration projects.
During the reporting period, WFP
committed about 25 percent of

food aid resources to projects cofunded with sister UN agencies, such as UNHCR, for rehabilitation projects aimed at facilitating reintegration and settlement of returnees in their homes of origin through shelter reconstruction and quick impact rural rehabilita-

\section{GENDER ISSUES}

The AprilMay 1995 mission's attention to gender issues as central to social equity considered both women's and men's need's in the specific context of the refugeesituation in Pakistan, keeping in view their eventual repatriation to Afghanistan. It also addressed the situation of women, actual and potential, in side Afghanistan.

\section{PAKISTAN}

Afghan refugee women, already disadvantaged by a culture of gender relations which favors males, now experience different forms of suffering associated with prolonged armed conflictand displacement from their communities of origin. Domestic violence is reportedly on the increase and many women, now widowed, often have to assume the responsibilities of heads of households, without the benefit of traditional forms of familial or communal support.

Although cultural traditions tend to disadvantage women as compared to men, observed variation in the condition of Afghan refugee men and women uncierscores the importance of recognizing differences among wornen and men, as a function of socio economic status.

While some categories of women can be readily, and appropriately, designated "vulnerable,"they share this status with men. More fundamental than gender identity as an obstacle to access to food is the very structure of camp social organization, and the existing system of distribution of food and other resources.

As an alternative to focusing on individual vulnerability, it is recommended that food and other forms of U.N. support be channeled to address collective vulnerability within the framework of community services/projects (e.g. BHUs, girls'education, community health and sanitation projects, and income generating activities). Consistent with the ongoing efforts of rehabilitation inside Afghanistan, these forms of support should continue to generate transferable assets (whether material, skills or organizational), which would enable repatriation, early self-reliance in Afghanistan and, ultimately, contribute to the reconstruction of Afghanistan.

There is no doubt that difficulties exist for working with Afghan refugee women. Nevertheless, it is important to guard against the "culture as obstacle"rationalization of insufficient attention to the needs of women (parallel to men) of disadvantaged households. "Resistance" to innovative approaches of reaching women, and promoting gender equity should not be assumed a priori. At the same time, surveying the repertoire of existing skills among the refugee population would help prevent unnecessary waste of valuable resources on "training" activities which are integral to the socialization of females and males in Afghan society.

(Continues..) 
tion projects.

Collaboration with UNDP, through Rehabilitation Steering Committees (RSC), organized in each of the five major regions in Afgharistan, provided a mechanism to enhance joint UN reha- bilitation activities. This process of pooling valuable UN resources has benefited the communities assisted by UNDP/OPS and WFP. In addition, consultations, exchange of information on various UN agency activities and preparation of regional quarterly reha- bilitation plans on al! UN agency rehabilitation activities in Afghanistan, ensured better focus on rehabilitation activities and at the same time facilitated in- depth agency-to-agency contacts.

Through the Rehabilitation Steer-

(...Continuation)

\section{AFGHANISTAN}

Commitment to gender equity in the identification and implementation of projects in Afghanistan requires the extension of this very principle to the administrative structures of the UN agencies engaged in relief and rehabilitation operations. It is therefore recommended that these agencies make a concerted effort to recruit female field officers (to work as members of teams with male counterparts). Input based on direct access to social collectivities of women and men is necessary if the concept of "community participation"' is to acquire operational utility.

In pursuit of alternatives to standardWID activities, the UN's (UNDP/OPS) Rehabilitation Steering Committee has nominated various UN agencies in different parts of Afghanistan as focal agency to help channel ideas, energy and resources constructively. Initial steps have been taken to implement a participatory approach which involves women directly in the identification of their communities' needs through the formation ofWomen's Management Groups. Through the efforts cf Women's Management Groups, Afghan women's own ideas (notthose imposed by NGO or UN agencies) are receiving public scrutiny, and endorsement, through an innovative procedure of project identification which overcomes the problem of male-female segregation.This entails the use of bulletin boards at mosques to exhibit lists of project options, and the priorities eventualiy selected foliowing due deliberations. Reiated to this innovative measure is the idea of promoting public monitoring of projects, and specification of accountability in project implementation.

In working with NGOs as implementing partners, WFP must exercise greater selectivity, and even when WFP partnerships involve reliable, gender sensitive NGOs, it is still necessary that qualified WFP female staff get involved in needs assessment, implementation, and monitoring and evaluation. Within the framework of a community-based participatory approach the time and effort ofWFP stalf in these exercises will be minimized.

As the bulk ofWFP's programme is implemented by both intemational and national NGOs in Afghanistan,WFP will identify and select those NGOs which are capable of carrying out gender specific planning, targeting and distribution, as well as the monitoring of performance with particular regard to gender issues. To the extent possible, priority will be accorded to those NGOs that are able to fulfill WFP's commitment to have food distributed through women (women's groups/associations) and directly to women within targeted households. In this connection, the expected recruitment of two female professional staff members for the Afghanistan programme is in line with this objective. Moreover, consistent with the recent food assessment mission to Afghanistan, which included a gender focus, WFP plans an evaluation of the Afghanistan PRO in Novernber 1995 which will likewise have a focus on gender. 
ing Committees, issues such as local authority contacts, capacity building.community participation, implementing partners and implementation modalities of each UN agency are discussed to arrive at an approach consistent in matters of policy and practice to enhance impact, increase visibility and maximize cost effectiveness of UN agencies' rehabilitation activities. This resulted in the establishment of working groups in each region to ensure better coordination and collaboration among UN agencies.

On the humanitarian relief front; coordination by UNOCHA for inter-agency needs assessment missions, in disaster and emergency-prone areas, facilitated speedy intervention by UN agencies to provide life sustaining assistance. UNOCHA's assumption of IDP camp management responsibility made them WFP's closest operational partner in the Jalalabad area, jointly with the provincial repatriation department. Donor briefings on the status of the UN Consolidated Appeal for Afghanistan and a series of inter-agency coordination meetings were organized by UNOCHA during the reporting period.

The reformulation of common UN policies for assistance to internally displaced persons in the country were jointly pursued by UNOCHA and UNHCR. This effort led to the adoption of a common policy on the gradual phasing down of care and maintenance rations to IDPs in camps and implementation of a de-registration system for IDPs voluntarily returning to their home of origin. Successful implementation of this strategy will lead to the release and reallocation of care and maintenance resources for reintegration of returning IDPs.

Collaboration with UNCHS (Habitat) focused on urban rehabilitation projects through joint urban sanitation projects and multipurpose urban rehabilitation projects. Collaboration with WHO and UNICEF focused on rehabilitation of health delivery systems, human resource rehabilitation and social improvement through institutional feeding projects in hospitals, the immunization campaign in Afghanistan, education, rehabilitation of health centers and income generating projects for youth and women.

Collaboration with FAO focused on crop production to ensure food security. During the reporting period WFP committed 1,500 MT of wheat to the FAO foodfor-seed project to retrieve viable germ plasma from farmers in exchange for WFP wheat for further distribution to farmers after treatment by FAO.

Pilot cooperation projects with UNOPS for rural rehabilitation projects is ongoing in the west of Afghanistan, with elements for co-funding of projects, technical support and monitoring of technical projects. In the noith, tripartite funding of the emergency rehabilitation of water intakes along the Balkh river is being negotiated with an input of $500 \mathrm{MT}$ wheat from WFP as a lead agency for the project, US\$ 40,000 from UNHCR to be technically superyised by UNOPS, who are also providing the necessary gabions. In the southern operation, cofunding of projects with UNHCR led to investment of US $\$ 150,000$ by UNHCR to food aid projects. Collaboration between WHO, UNOCHA and WFP led to the rehabilitation of the water supply system in Kandahar. WFP also availed itself of monitoring costs for the bakery projects from UNHCR in Herat, Mazar and Kandahar during the reporting period.

To consolidate the excellent interagency cooperation which WFP has enjoyed, memoranda of understanding (MOU) with various sister UN Agencies are now being negotiated. This will ensure reciprocal commitment of technical and financial services against specified levels of WFP commodities

The first such draft Memorandum of Understanding (MOU) has been formulated with FAO and is now being reviewed by FAO and WFP Headquarters. Similar MOUs with WFP's principal UN partners will follow, and will in- 
clude UNDP as the principal Faizabad, local municipalities are source of funding for major partners such as UNOPS, Habitat, FAO and UNDCP. with functioning Government departments:

During the reporting period, adoption of the "peaceful area" policy made provisions for an increase in collaboration with functioning government departments in the country. In the west of Afghanistan, the Rural Rehabilitation Department (RRD), a unit of the Ministry of Rural Rehabilitation, is the main implementing partner of WFP with over 3,000 MT of food aid committed for projects undertaken by the department. In Kandahar, Mazar, Herat and

the main WFP implementing partners for bakery projects in partnership with local unions of bakers.

\section{- Cooperation with NGOs and implementa- tion of the umbrella project concept.}

NGOs are the main WFP implementing partners in Afghanistan. Streamlining the cooperation with NGOs, through the umbrella projects concept, demonstrated its advantage by limiting the number of direct NGO implementing partners accountable to WFP. The concept made provision for a group of NGOs working together under a donor NGO or a reputable national NGO, or a group of governmental depart-

\section{- Increase cooperation}

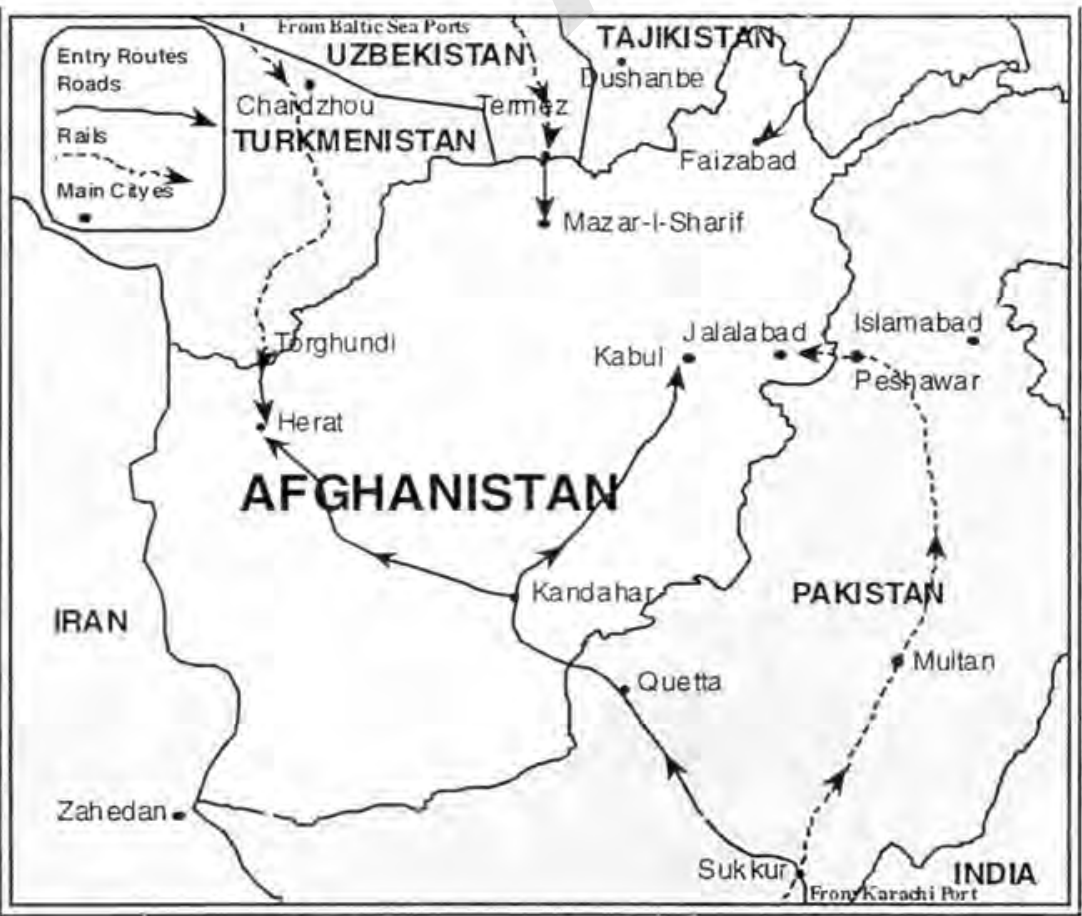

ments, with provisions for training of smaller NGOs/governmental departments in the utilization of food aid as an investment resource in socio-economic recovery. Umbrella projects were initiated at most sub-offices, during the reporting period, with ACBAR, an NGO coordinating body responsible for the bakery project in Kabul; and with SWABAC and ANCB, coordinating bodies of NGOs operating in the south and east of Afghanistan, respectively. SWABAC implemented an umbrella project in collaboration with 17 national NGOs working on rural rehabilitation projects in the south of the country.

\section{INCORPORATION OF UNILOG (LOGISTICS)}

The incorporation of UNILOG into the Afghanistan Country programme from the Pakistan Country Office, was a major sequenced undertaking, including a series of discussions and workshops, in collaboration with the WFP Pakistan Country Office, to support an orderly transfer of UNILOG to the Afghanistan operation. With the overall management of UNILOG now under WFP Afghanistan, the official transfer of legal, financial and personnel responsibility is expected to take effect in September 1995. 
PROGRAMME In total, 280,000 internally disACHIEVEMENTS $B Y T Y P E$ IDP CARE AND MAINTENANCE:

TA.JIK REFUGEES With the prevailing tranquillity in

Provision of care and maintenance food rations to over 270,000 internally displaced persons in camps in Jalalabad, Mazar and public buildings in Kabul constituted a major component, of WFP food activities during the reporting period. Of total resources utilized during the reporting period, 35.5 percent $(18,840 \mathrm{MT})$ were distributed for care and maintenance feeding of internally displaced persons in camps in various parts of the country and for the Tajik refugees in the north. placed persons and refugees availed themselves of WFP food assistance from January to June 1995.

Kabul from April to June, and the voluntary repatriation of internally displaced persons that followed, a gradual phasing down of care and maintenance rations to IDPS in camps, especially in the Jalalabad area, was implemented by WFP in close collaboration with implementing partners.

This entailed the following:

Suspension of distribution of mixed commodities (effective May 1995) as a disincentive measure to prevent dependency by providing only wheat to IDPs.

- Implementation of a 50 percent reduction of wheat rations for IDPs who have spent more than two years in Mumtaz and Old Hadda camps in Jalalabad, followed by a complete phasing out of wheat rations to these camps by end of June 1995. As a safety net, provision for vulnerable groups (after re-validation) has been planned.

Gradual reduction of wheat rations to IDPs in Sarshahi and New Hadda camp in Jalalabad, de-registration of IDPs voluntarily repatriating from these camps on presentation of ration cards and provision of a repatriation package including wheat.

Provision for food-for-

Food Distribution by Programme Componenet January - June 1995

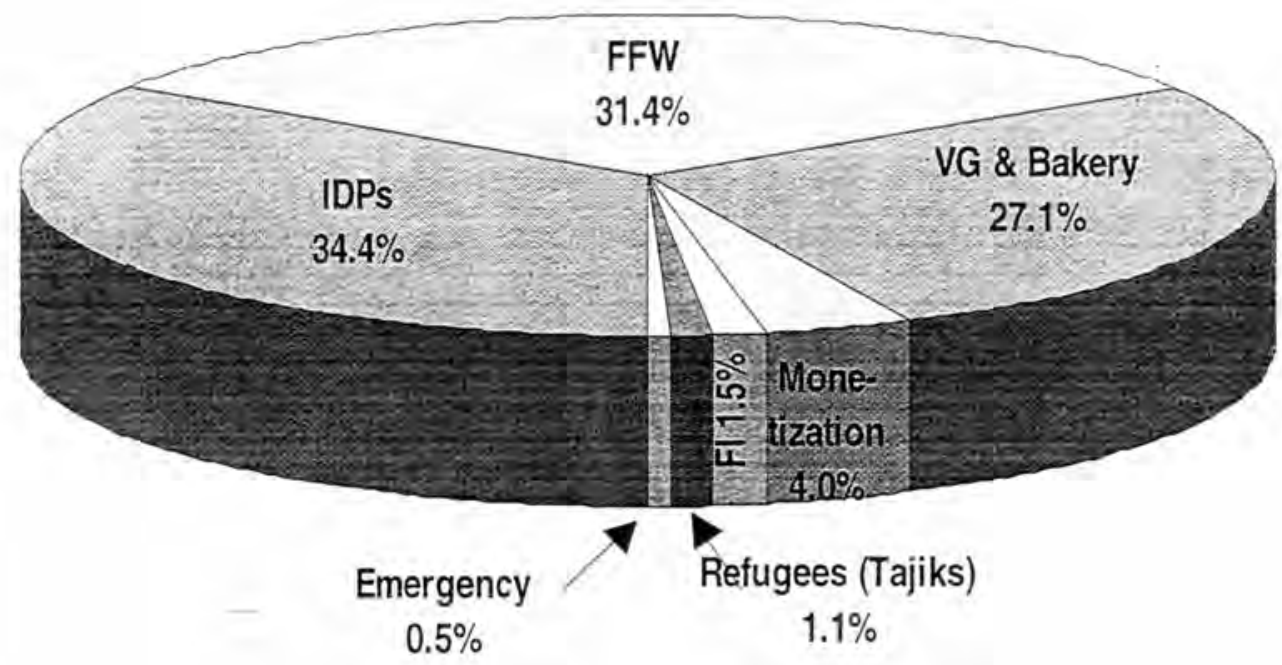


work and food-for-training opportunities for the residual camp population that will stay, through labour bureaus established in camps, in collaboration with the department of repatriation, $\mathrm{UN}$ agencies and NGOs.

During the reporting period, provision of mixed (multiple food items) rations to IDPs in camps in Afghanistan was terminated. Provision of wheat rations to IDPs in Mumtaz and Old Hadda camp in Jalalabad was phased out at the end of June 1995. Provision of care and maintenance rations to IDPs in Sarshahi and New Hadda camps in Jalalabad is gradually being phased down. To get a precise number of camp residents in the two camps, a deregistration system for IDPs voluntarily returning was established at Sarshahi and New Hadda camps. To facilitate reintegration of internally displaced persons voluntarily returning, a repatriation package on a sliding scale (after implementation of de-registration) was implemented and is ongoing.

In the north, care and maintenance for IDPs was terminated in March 1995, which resulted in a series of demonstrations and protests from IDPs in Kamaz camp in Mazar. To resolve the problem, an inter-agency agreement was reached to provide two months rations to the Kamaz camp IDPs, with the understanding that no further distribution will be made. As at 27th June 1995 . a residual population 17,942 internally displaced persons remain in Mazar.

Norepatriation of Tajik refugees from Sakhi camp in the north took place during the reporting period, although 30 refugees registered for repatriation. As at 30 th June 1995, the population of Tajik refugees in Sakhi camp in Mazar is 1,054 families. From SherKhan-Bander in Kunduz province, 350 Tajik refugees returned during the reporting period according to UNHCR.

\section{FOOD-FOR-WORK} PROJECTS

Food-for-work projects, in partnership with sister UN agencies, NGOs, functioning governments and local shuras, constituted another major component of the programme activities during the reporting period. Of the total food resources utilized during the reporting period, 31.4 percent (16.704 MT) were allocated for people-oriented and communitybased rehabilitation activities. 200,000 beneficiaries availed themselves of WFP assistance through food-for-work projects from January to June 1995.

These projects supported poverty alleviation activities that stimulate rural rehabilitation through self-help initiatives and facilitate reintegration and resettlement of returning Afghan refugees.

Key physical achievements through food-for-work projects during the reporting period included the following:

- Rehabilitation of 284.1 $\mathrm{km}$ essential farm to market roads and construction of 244 units of culverts/bridges. These projects improved access to over 300 agricultural villages.

- Repair and cleaning of $530.4 \mathrm{~km}$ of irrigation canals that provide irrigation water for over 40,000 hectares of agricultural land.

Reconstruction of 15 war-damaged schools with enrollment capacity of $6,300 \mathrm{pu}$ pils in two shifts.

Shelter reconstruction assistance for rehabilitation of 9,754 houses to facilitate reintegration and settlement of 68,278 returnees.

\section{- Removal of 50,000 cu-} bic meters of garbage from urban centers, improving sanitary conditions for urban residents in Jalalabad, Mazar, Herat and Kabul.

Vocational training of 3,929 people in various income generating activities. 
a Cleaning of 257,600 linear meters of karezes in the country that provide drinking water and irrigation water to rural and urban areas.

Construction of 1,474 meters of flood protection walls that protect over 50 villages from flood damage.

a Rehabilitation of 21,612 hectares of agricultural land.

ㄹ Planting of 50,000 trees.

anabilitation of seri-cultural activities in Mazar, within which women play a major income-earning role in related cottage industries for production of silk.

\section{VULNERABLE GROUP FEEDING PROJECTS}

With growing urban poverty in Afghanistan, vulnerable group feeding projects, mainly through the bakery projects and through institutional feeding at provincial referral hospitals, constituted a significant component of WFP activities during the reporting period. Of total resources utilized from January to June 1995, 29 percent $(15,217 \mathrm{MT})$ were received by beneficiaries under this component.

Wheat was provided to urban bakeries at low cost to bake bread and sell at highly subsidized prices to the urban poor and vulnerable groups in Herat, Mazar, Kandahar, Faizabad, Kabul and Jalalabad. Beneficiaries included widows, orphans, street children, the elderly, disabled, displaced persons and the urban poor, including returnees.

The objective of the bakery project is to prevent hunger and starvation among the urban poor and vulnerable groups during winter and lean periods. These bakery project interventions have also had a positive effect on stabilizing wheat prices on the local markets.

To reduce dependency on food aid and generate local resources for reinvestment in productive rehabilitation activities, the bakery projects were modified in Herat, Kabul and Mazar to include a two tier pricing system. The first tier with a 100 percent wheat flour subsidy, targets the most vulnerable groups of the cities. This category of beneficiaries paid the equivalent of the baking cost of the bread. The second tier, with an average 50 percent wheat flour subsidy, targeted mainly the urban poor and returnees.

Through the two tier pricing system, the Herat sub-office, for example, generated over one billion Afghanis (US\$250,000) during the reporting period. Proceeds from the bakery project were uti- lized for reinvestment in the region by providing complementary inputs for food-for-work projects to improve the quality of projects undertaken. About 408,000 poor Afghan beneficiaries availed themselves of WFP assistance through the bakery projects.

The bakery projects reduce pressure on the wheat market during winter and contribute to keeping wheat prices at affordable levels. To ensure that the market prices of wheat are not distorted with a disincentive effect on food production, the bakery projects are suspended when the market price of wheat falls very low and they are generally stopped with the onset of harvesting.

Beneficiaries of the bakery projects were identified by task forces at each sub-office, comprising local municipality authorities, section leaders, elders, WFP and $N G O$ representatives, where applicable. The projects at all sub-offices were implemented in partnership with the local municipality authorities and the union of bakers at each location.

In Herat, Mazar and Kandahar. monitoring costs of the project were paid by UNHCR for monitors recruited and trained by WFP In Jalalabad, monitoring was carried out by an NGO funded by WFP. The bakeries 
projects have been identified as having economic potential to become viable women-managed enterprises.

Institutional feeding projects targeted mainly referral hospitals in main provincial capitals supported by UNICEF, WHO or directly through Health authorities or major NGOs. During the reporting period, institution feeding projects covered the main referral hospitals in Kabul, Herat, Mazar, Jalalabad and Kandahar. 


\section{IMPLEMENTATION}

\section{PROBLEMS / CONSTRAINTS}

\section{RESOURCE CONSTRAINTS}

Lack of sufficient resources, especially cash and late arrival of pledges are affecting the 1995 programme for Afghanistan. WFP estimates that $2 / 3$ of total resources should be allocated to the southern pipeline (via Pakistan) while $1 / 3$ should be sent via the northern pipeline from the Baltic ports. The actual allocation to the north is well below the $1 / 3$ target and this has resulted in low stocks in the Mazar and Herat sub-offices traditionally supplied through the northern pipeline. The lack of resources at the two suboffices have resulted in lowerthan-anticipated programming of food aid during the reporting peniod.

Due to the additional food requirements for the internally displaced persons as well as the Kabul emergency of 1994, the UNOCHA-coordinated UN Consolidated Appeal for Afghanistan (October 1994-September 1995) included an appeal for an additional 78,335 MT of food aid. Unfortunately, only 14 percent of the requested, additional amount has been resourced from the UNOCHA Appeal.

The low funding of the UN consolidated appeal to meet the additional requirements for intemally displaced persons and the Kabul emergency has resulted in the transfer of resources from the regular rehabilitation programme to meet the emergency requirements of the internally displaced. This development has necessarily led to a reduction in the expected coverage of the 1995 regular programme to support rehabilitation activities in other parts of the country.

\section{OPERATIONAL CASH CONSTRAINTS}

The budget for operational support to the 1995 regular-programme shows a deficit of US\$ 1.4 million against an original requirement of US\$ 3.3 million. In addition, no recent cash pledges have been received from donors against the US\$ 780,000 additional operational cost requirements in support of the operations for the internally displaced persons and the Kabul emergency, not covered by the CFA approved operational budget.

The existing shortfall of cash pledges, against the operational budget requirements for the 1995 programme, is creating serious constraints for the smooth implementation of the 1995 programme. The lack of equipment and vehicles to follow up programme activities is creating immense pressure, stress and frustration for field staff at the suboffices.

The Programme stands to lose its
UNV monitors, financed during the last two years on the basis of a special humanitarian contribution from the UNDP IPF funds. Posts for UNV specialists assigned to WFP may no longer be financed through the UNDP IPF funds. Considering the need for international monitors to support programme activities, losing the existing UNVs will seriously affect WFP's capacity to monitor ongoing programme activities.

\section{LACK $O F$ EFFECTIVE IMPLEMENTING PARTNERS}

The commercial orientation and other weakriesses (technical and management) of existing national NGO implementing partners in Afghanistan are a significant constraint, affecting programme implementation in the country, overburdening WFP personnel who must closely monitor projects undertaken by NGOs in the absence of functioning government departments in many parts of the country. To overcome this bottleneck, the Country Office, through the seven sub-offices, have undertaken a review of existing implementing partners within the umbrella project concept to limit the number of direct implementing partners of WFP and screen-out all NGOs with poor performance records. 


\section{OTHER CONSTRAINTS}

a. Growing urban poverty and the wide-spread collapse of rural and urban infrastructures in the country, exacerbated by the absence of local government structures to support indigenous reconstruction activities, result in a high degree of reliance on WFP resources for most relief needs and support for rehabilitation activities.

b. The continued political instability in pockets of the country, problems of land mines and lack of vehicles and human resources at the sub-offices, is affecting the extent to which WFP can reach the hungry and poor in remote parts of the country. Furthermore, the lack of implementing partners willing to work in remote areas in the country limit, to some extent, the outreach capacity of WFP to very remote areas. 


\section{Commodity Availability and Shortfalls}

\begin{tabular}{|c|c|c|c|c|c|c|c|}
\hline \multicolumn{8}{|c|}{ SUMMARY FOR SIX MONTHS (July-December 1995) } \\
\hline & KABUL: & MAZARK & FAIZABAD & HERAT: & KANDAHAR & JALALABAD' & TOTAL \\
\hline Total Requirements (MT) & 19,110 & 17,743 & 5,528 & 16,519 & 16,066 & 25,200 & 100,166 \\
\hline Initial Stock (MT) & 3,983 & 7,821 & 698 & 960 & 5,414 & 13,296 & 32,172 \\
\hline Total Expected Deliveries (MT) & 5,000 & 6,900 & 2,000 & 3,200 & 5,000 & 8,000 & 30,100 \\
\hline Shortfall (MT) & 20,127 & 16,822 & 6,830 & 18,759 & 15,652 & 19,904 & 98,094 \\
\hline Available/Requirements (\%) & $47 \%$ & $83 \%$ & $49 \%$ & $25 \%$ & $65 \%$ & $85 \%$ & $59 \%$ \\
\hline BREAKDOWN BY MONTH & 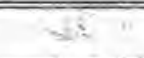 & 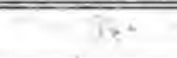 & (1): & $\overline{-1 .}$ & & +2 & \\
\hline July & & & & & 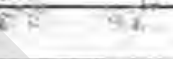 & +2 & \\
\hline Total Requirements (MT) & 3,185 & 2,957 & 921 & 2,753 & 2,678 & 4,200 & 16,694 \\
\hline Initial Stock (MT) & 3,983 & 7,821 & 698 & 960 & 5,414 & 33,296 & 32,172 \\
\hline Expected Deliveries (MT) & . & & . & 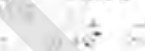 & & & $\therefore$ \\
\hline Shortfall (MT) & . & . & 223 & 1,793 & $=$ & 8 & 2,017 \\
\hline Available/Requirements (\%) & $100 \%$ & $100 \%$ & $76 \%$ & $35 \%$ & $100 \%$ & $100 \%$ & $100 \%$ \\
\hline \multicolumn{8}{|l|}{ August } \\
\hline Total Requirements (MT) & 3,185 & 2,957 & 921 & 2,753 & 2,678 & 4,200 & 16,694 \\
\hline Initial Stock (MT) & 798 & 4.864 & . & - & 2,736 & 9.096 & 17,494 \\
\hline Expected Deliveries (MT) & . & , & . & . & . & . & . \\
\hline Shortfall (MT) & 2,387 & - & 921 & 2,753 & . & - & 6,062 \\
\hline Available/Requirements $(\%)$ & $25 \%$ & $100 \%$ & $0 \%$ & $0 \%$ & $100 \%$ & $100 \%$ & \\
\hline \multicolumn{8}{|l|}{ September } \\
\hline Total Requirements (MT) & 3,185 & 2,957 & 921 & 2,753 & 2,678 & 4,200 & 16,694 \\
\hline Initial Stock (MT) & . & 1,907 & - & . & 59 & 4,896 & 6,861 \\
\hline Expected Deliveries (MT) & - & - & - & - & $x-$ & - & $\therefore, 1$ \\
\hline Shortfall (MT) & 3,185 & 1,051 & 921 & 2,753 & 2,619 & - & 10,529 \\
\hline Available/Requirements (\%) & $0 \%$ & $64 \%$ & $0 \%$ & $0 \%$ & $2 \%$ & $100 \%$ & \\
\hline \multicolumn{8}{|l|}{ October } \\
\hline Total Requirements (MT) & 3,185 & 2,957 & 921 & 2,753 & 2,678 & 4,200 & 16,694 \\
\hline Initial Stock (MT) & - & - & - & - & - & 696 & 696 \\
\hline Expected Deliveries (MT) & . & - & 2,000 & - & . & - & 2,000 \\
\hline Shortfall (MT) & 3,185 & 2,957 & - & 2,753 & 2,678 & 3,504 & 15,077 \\
\hline Available/Requirements (\%) & $0 \%$ & $0 \%$ & $100 \%$ & $0 \%$ & $0 \%$ & $0 \%$ & \\
\hline \multicolumn{8}{|l|}{ November } \\
\hline Total Requirements (MT) & 3,185 & 2,957 & 921 & 2,753 & 2,678 & 4,200 & 16,694 \\
\hline Initial Stock (MT) & - & - & 1,079 & - & - & - & 1,079 \\
\hline Expected Deliveries (MT) & 5,000 & 5,000 & . & 2,000 & 5,000 & 8,000 & 25,000 \\
\hline Shortfall (MT) & . & . & . & 753 & . & . & 753 \\
\hline Available/Requirements (\%) & $100 \%$ & $100 \%$ & $100 \%$ & $73 \%$ & $100 \%$ & $100 \%$ & \\
\hline \multicolumn{8}{|l|}{ December } \\
\hline Total Requirements (MT) & 3,185 & 2,957 & 921 & 2,753 & 2,678 & 4,200 & 16,694 \\
\hline Initial Stock (MT) & 1.815 & 2,043 & 157 & . & 2.322 & 3,800 & 10,138 \\
\hline Expected Deliveries (MT) & - & 1,900 & - & 1,200 & - & . & 3,100 \\
\hline Shortfall (MT) & 1,370 & . & 764 & 1.553 & 355 & 400 & 4,443 \\
\hline Available/Requirements (\%) & $57 \%$ & $100 \%$ & $17 \%$ & $44 \%$ & $87 \%$ & $90 \%$ & \\
\hline
\end{tabular}

"Stock figures for Kabul include the ones in Quetta, the ones for Mazar include the stock fogures for Termez and Hairaton stock figures for Herat include the ones from Torghundi and the figures for Jalalabad include the stock for Peshawar. 


\section{Commodity availability (\%) and shortfall (mt)}

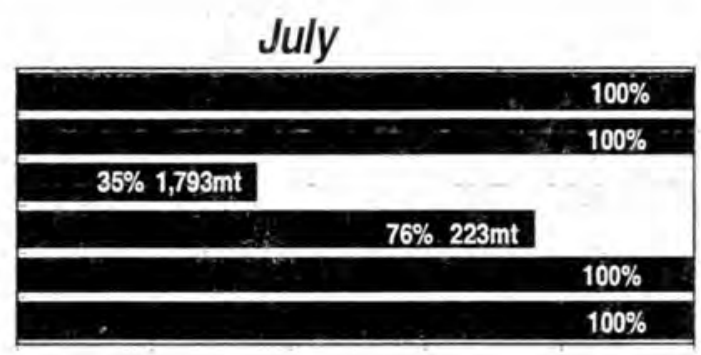

$\begin{array}{llllll}0 \% & 20 \% & 40 \% & 60 \% & 80 \% & 100 \%\end{array}$

\section{September}

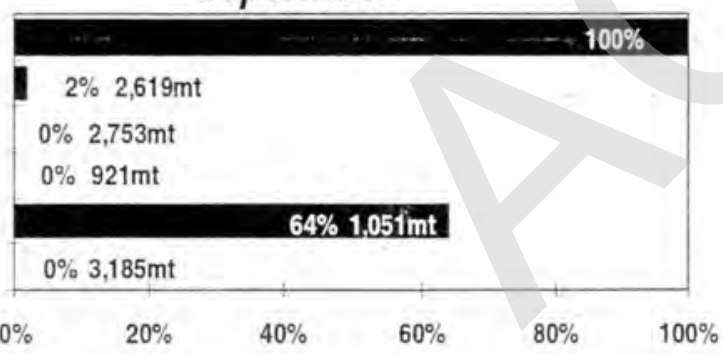

\section{November}

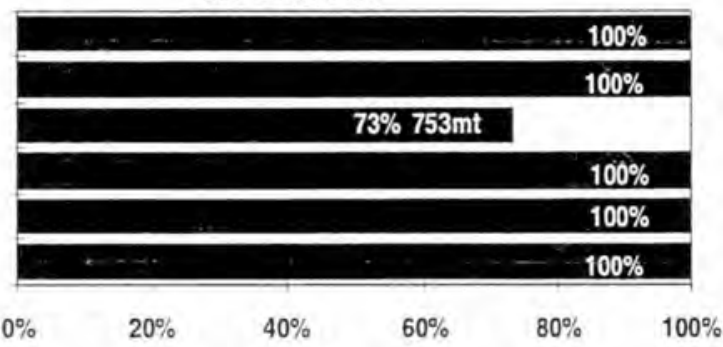

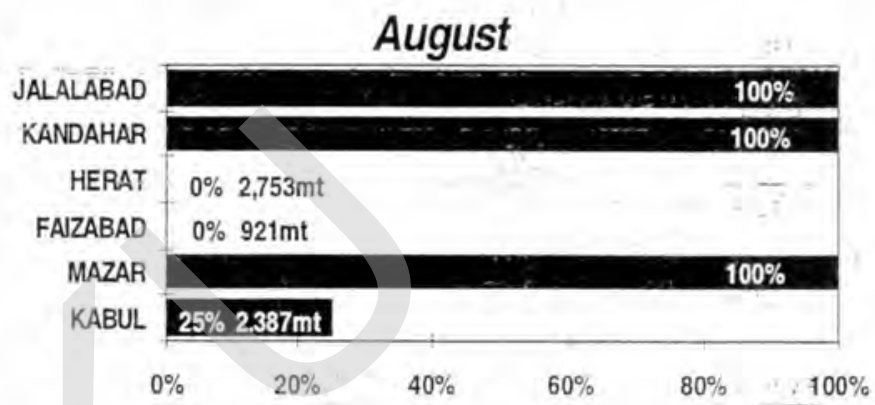

October

\begin{tabular}{|c|c|}
\hline JALALABAD & $0 \% 3,504 \mathrm{mt}$ \\
\hline KANDAHAR & $0 \% 2,678 \mathrm{mt}$ \\
\hline HERAT & $0 \% 2,753 \mathrm{mt}$ \\
\hline FAIZABAD & \\
\hline MAZAR & $0 \% 2,957 \mathrm{mt}$ \\
\hline KABUL & $0 \% 3,185 \mathrm{mt}$ \\
\hline
\end{tabular}

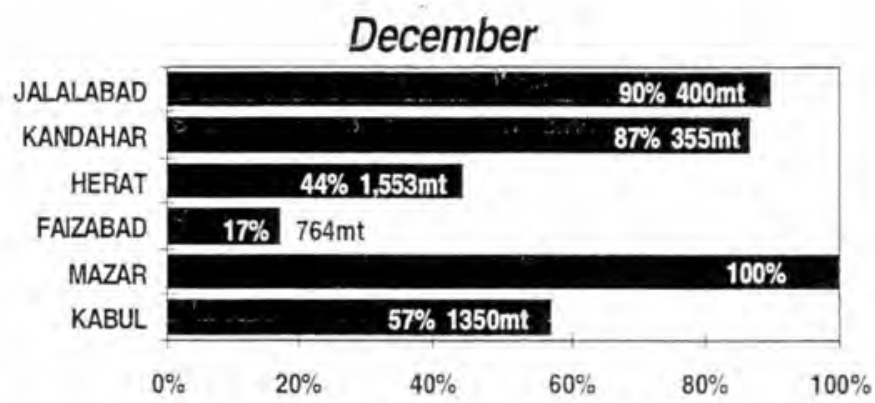




\section{STRATEGY FOR}

\section{THE SECOND HALF OF 1995}

\section{JULY - DECEMBER 1995}

The Country Office organized a mid-year programme review workshop, attended by all suboffice Heads in July 1995. The objectives of the workshop were to review the 1995 programme goals, conclusions and decisions taken at the February 1995 programme workshop, programming procedures/project approval, sub-office achievements and review of resource availability for the second half of 1995.

This was followed by further clarifications of inter-agency agreements, monetization policies, monitoring with assistance of NGOs, review of NGO implementing partners and discussion of administrative and finance related matters.

As a result of deliberations during the mid-year programme review workshop, the following strategies for the remainder (second half) of 1995 were agreed upon:

Adjustment of targets: Targets for all sub-offices are being adjusted to reflect the actual availability of resources to the end of the year, estimated at around 100,000 MT of food aid as shown in the table on page 31 .

- Increase cooperation with sister UN agencies at all suboffices to ensure access to complementary inputs and technical support for joint food aid projects.
Continue the review of for current ongoing projects with existing implementing partners at completion dates beyond the each sub-office, based on past quarter in question.

experience, and increase umbrella projects to limit the number of direct implementing partners.

- Increase cooperation with functioning Government departments at each sub-office with umbrella projects, in peaceful areas.

- Ensure local and counterpart contributions as a precondition for access to WFP resources.

\section{- Utilize Rural Develop-} ment Funds (RDF) to effect payment of administrative costs for projects being implemented by NGOs with cash or through centralized monetization by sub-offices to effect payment. NGOs will not be allowed to monetize WFP resources to recover administrative costs.

\section{- Increase use of reputable} NGO partners/contracted monitors/volunteer collaborators and sister UN agencies to ensure effective monitoring of food aid projects.

\section{- Increase programming of} food aid projects in rural areas, food deficit areas and areas of year-round endemic unemployment to influence return of people to their area of origin.

\section{- Double food aid utiliza-} tion at each sub-office by not blocking existing stocks approved
Prepare quarterly food aid requirement plans to capture RDF requirements for administrative costs of projects, non-food items, skilled labour and other project support costs.

Implement bakery projects at all sub-offices, with a two tier pricing system for vulnerable groups and the urban poor, and ensure higher female partecipation rates in management of the bakeries.

\section{Continue introduction of} literacy classes in all vocational training projects supported by WFP.

Expand projects that mobilize the "lost generation" of Afghanistan through vocational training projects.

Continue phase down of care and maintenance feeding at IDP camps in Jalalabad in favor of productive food-for-work rehabilitation projects.

- Prepare regular updates on pipeline projects at each suboffice.

Follow up regional procurement with WFP Headquarters to replenish stocks in Mazar and Herat Country Offices.

Identify suitable female candidates for recruitment into the WFP staffing complement. 
The WFP programme for Afghanistan in 1996 will continue to support people-oriented and community-based rehabilitation activities on a larger scale and continue the process of phasing down care and maintenance rations for internally displaced persons in camps in favor of productive food-for-work rehabilitation projects. As such, the focus beyond 1995 will aim towards the utilization of food aid as an investment resource in the socio-economic recovery process of Afghanistan.

In reaching the hungry and poor beyond 1995, the programmatic emphasis will be on the provision of emergency assistance on a short term basis and promotion of grassroots initiatives for rehabilitation of productive infrastructures through labour intensive works that simultaneously pro- vide employment opportunities for the poor and disadvantaged, support poverty alleviation activities and strengthen self help capacities.

Activities with immediate income generating activities to facilitate reintegration and consolidate resettlement of returnees will be emphasized as the ongoing protracted refugee operation moves towards a regular programme for Afghanistan.

Priority areas for utilization of food aid beyond 1995 will continue to focus on food deficit areas, areas of recent return, poppy substitution areas, strategic areas for WFP transport activities, peaceful areas with functioning government departments, deprived and war-affected areas, areas of yearround endemic unemployment and emergency/disaster prone areas.
In view of the limitation of the use of food aid in the absence of government financial, administrative and technical support, the W.FP programme beyond 1995 will increasingly collaborate with sister UN agencies, functioning govemment departments and NGOs (through umbrella projects) to maximize the productive impact of food aid.

As completion of the refugee repatriation programme is anticipated by UNHCR by the end of 1996, WFP will have to gradually shift towards a regular programme mode. As of 1997, the operations will have to coexist with a regular programme which must be ready to move into adevelopment-oriented country programme, as the political a peace process reach fruition. 
More detailed information on specific situations referred to in this report is available from WFP. Enquiries should be directed to, Jeffrey Taft-Dick, Senior Desk Officer, Mediterranean, Middle East and Eastern Europe Bureau, OMM, WFP Headquarters, Via Cristoforo Colombo No. 426,00145 Rome, Italy. Tel: +3965228-2323, Fax: + 39 65228 2851. E-mail: taftdick@wfp.org 


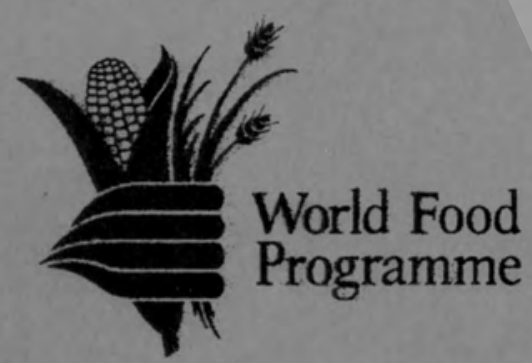

WFP Headquarters Rome

Via Cristoforo Colombo 426

00145 Rome, Italy

Telephone: (0039) 652282323

Fax: (0039)652282851

WFP Afghanistan Country Office

(temporarily in Islamabad, Pakistan)

Telephone: (00 92) 51222148

(0092) 51828934

(0092) 51828874

Fax: (0092)51212723
WFP New York Liaison Office

Room DC1-1027

One United Nations Plaza

Telephone: (00 1) 212 963-8440

New York, N.Y 10017

Fax: (00 1) 212963-8019

Telex: 62450

WFP Geneva Liaison Office

Palais des Nations

CH-1211 Geneva 10

Switzerland

Telephone: (0041) 229799569

Fax:(0041) 229799018 